Karadeniz Uluslararası Bilimsel Dergi

Volume: 47, Autumn-2020, p. (222-255)

ISSN: 1308-6200 DOI Number: https://doi.org/10.17498/kdeniz.767227

Research Article

Received: July 9, 2020 | Accepted: September 1, 2020

This article was checked by intihal.net.

\title{
ARDAHAN İLİ 2017 YILI ARKEOLOJİK YÜZEY ARAŞTIRMASI
}

\author{
FIELD SURVEYS IN ARDAHAN IN 2017
}

\section{АРХЕОЛОГИЧЕСКИЕ ИССЛЕДОВАНИЯ ПОВЕРХНОСТИ АРДАХАНСКОЙ ПРОВИНЦИИ В 2017 ГОДУ}

\author{
Sami PATACI \\ Özlem ORAL PATACI ${ }^{* *}$
}

\section{ÖZET}

Ardahan İli 2017 arkeolojik yüzey araştırması çalışmaları Ardahan'ın Merkez, Çıldır ve Göle İlçeleri'ne bağlı yerleşim alanlarında ve bu alanların yakın çevresinde gerçekleştirilmiştir. Buna göre, Merkez ilçede Ölçek, Gölgeli, Balıkçılar, Sulakyurt, Beşiktaş; Göle'de Çobanköy, Bellitepe, Kuzupınarı, Dedeşen, Çıldır'da Kotanlı, Eskibeyrehatun, Doğankaya ve Yıldırımtepe köyleri ve bu yerleşimlerin çevresi araştırılmıştır. 2017 yılında tespit edilen arkeolojik alanlar Ölçek-Kuzey Kalesi, Gölgeli Güneydoğu Kalesi ve Yerleşimi, Beşiktaş Kalesi, Yerleşimi ve Kurgan Mezarları, Çobanköy Kalesi ve Yerleşimi, Çobanköy Höyüğü, Kuzupınarı Kalesi ve Yerleşimi, Bellitepe'de iki kule ve bir ağıl ve Kotanlı yerleşimidir. Bunlar dışında Sulakyurt ve Doğankaya'da Demir Çağı ile Ortaçağ dönemlerine ait çanak çömlekler tespit edilmiş ve Çıldır'daki Şeytan Kalesi'nde de çalışılmıştır. Araştırmada Bronz ve Demir Çağ'dan kalma mimari kalıntıların yanı sıra, Bellitepe ve Dedeşen'de iki kilise ve Balıkçılar, Ölçek, Sulakyurt ve Eskibeyrehatun'da dört şapel tespit edilmiştir. Şapeller; dolgu duvar tekniğinde inşa edilmiş tek nefli tipik dini yapılardandır. Bellitepe ve Dedeşen Kiliseleri ise ek mekânları ve daha büyük boyutlarıyla şapellere göre daha karmaşık bir yapıya sahiptirler.

Anahtar Kelimeler: Ardahan, Demir Çă̆, Beşiktaş Kalesi, Orta Çă̆, Çıldır, Şeytan Kalesi.

\section{ABSTRACT}

Field surveys in Ardahan in 2017 were conducted in Çıldır, Göle and the central district of Ardahan. During the survey in 2017, settlements of Ölçek, Gölgeli, Balıkçılar, Sulakyurt and Beşiktaş in the central district; Çobanköy, Bellitepe, Kuzupınarı, Dedeşen in Göle

\footnotetext{
* ORCID: 0000-0003-1840-6562, Dr. Öğr. Üyesi, Ardahan Üniversitesi, İnsani Bilimler ve Edebiyat Fakültesi, Arkeoloji Bölümü. E-posta: samipataci@ hotmail.com.

** ORCID: 0000-0001-7604-9634, Dr. Öğr. Üyesi, Ardahan Üniversitesi, İnsani Bilimler ve Edebiyat Fakültesi, Sanat Tarihi Bölümü, E-posta: ozlemoral@ardahan.edu.tr.
} 


\section{Sami PATACI - Özlem ORAL PATACI}

district and finally Kotanlı, Eskibeyrehatun, Doğankaya and Yıldırımtepe in Çıldır were researched. Northern Fortress of Ölçek, Southeastern Fortress of Gölgeli and its settlement, Fortress of Beşiktaş with its settlement and the kurgan cemetery, Fortress of Çobanköy and its settlement, Çobanköy Höyük, Fortress of Kuzupınarı and its settlement, two towers and a sheep pen in Bellitepe and an ancient archaeological site in Kotanlı were detected in the survey. In addition, two sites of ceramic finds from the Iron Age and Medieval Period in Sulakyurt and Doğankaya were discovered and the Devil's Fortress in Çıldır was researched by our survey team. Besides the architectural ruins from Bronze and Iron Ages, two medieval churches in Bellitepe and Dedeşen and four chapels in Balıkçılar, Ölçek, Sulakyurt and Eskibeyrehatun were identified during the research. The chapels are from the typical single-naved religious buildings built in infill wall technique in Ardahan. Comparing to the chapels, the churches in Bellitepe and Dedeşen are more complex with their additional rooms and larger dimensions.

Keywords: Ardahan, Iron Age, Beşiktaş Fortress, Middle Age, Çıldır, Devil's Fortress.

\section{АННОТАЦИЯ}

В 2017 году в Ардаханской провинции в районах самого Ардахан, Чылдыр и Гёле были проведены археологические исследования поверхности, а также места в непосредственной близости от этих районов. Соответственно, в Ардазанском районе были проведены исследования в сёлах Ёлчек, Гёлгели, Балыкджылар, Сулакюрт, Бешикташ; в Гёлейском районе в сёлах Чобанкей, Беллитепе, Кузупынав, Дедешен; в Чылдырском районе в сёлах Котанлы, Ескибейрехатун, Доганкайя, и Ийлдырымтепе. В 2017 г. Были выявлены следующие Археологические памятники: северная крепость села Ольчек; юговосточная крепость и место поселения села Гёлгели; крепость, место поселения и курганные гробницы села бешикташ; Чобанкёй курган; крепость и место поселения села Кузупынар; две башни и загон в Беллитепе; место поселения села Беллитепе. Помимо этого изучена керамика, относящаяся к железному веку и средневековью, которая была найдена в Сулакюрте и Доганкая и проведена исследовательские работы на территории замка Шейтан Кале в Чылдыре. Кроме архитектурных памятников бронзового и железного веков, в ходе исследования были выявлены две церкви в Беллитепе и Дедешен и четыре часовни в Балыкджыларе, Ёльчеке, Сулакюрте и Эскибейрехатуне. Часовни, это одно из типичных религиозных сооружений с одним нефом, построенные по принципу заливки стен. С другой стороны, церкви Беллитепе и Дедешен имеют более сложную структуру, чем часовни с их дополнительными пространствами и большими размерами.

Ключевые слова: Ардахан, железный век, замок Бешикташ, средневековье, Чьлдыр, Шейтан Кале.

\section{Giriş}

Bu makalede; Ardahan'da 2017 yılında gerçekleştirilen yüzey araştırmasının bir değerlendirmesi yapılmaktadır. 2013 yılından itibaren yapılan yüzey araştırmalarında en yoğun eskiçă̆ savunma yapısı bu sezonda tespit edilmiş ve makalenin önemli bir kısmını bu savunma yapılarına ilişkin veriler doldurmuştur. Ancak bu arkeolojik alanlar sadece askeri işleve sahip olmayıp merkezinin, yakın çevresinin yahut tamamının sivil yerleşime ait yapı grupları ile dolu olduğu yerleşimler de mevcuttur. 2017 araştırması ilin merkez, Göle ve Çı1dır 
ilçelerinde gerçekleştirilmiştir. Tunç ve Demir Çağı buluntularının yanı sıra Ortaçağ’a ait kültür varlıkları da makalenin konusunu teşkil etmektedir.

\section{Ölçek Kuzey Kalesi}

Yüzey araştırmamızın önceki sezonlarında Ardahan il merkezinin $16 \mathrm{~km}$ doğusunda yer alan Ölçek Köyü'nün merkezinde ve bu köye bağlı bir mevkide yer alan iki arkeolojik alanda çalışılmıştı (Patacı ve Laflı 2016: 290-292; Patacı ve Laflı 2017: 115, fig. 3). 2017 yılında ise Ölçek köy merkezinin $3 \mathrm{~km}$ kuzeydoğusunda, $1860 \mathrm{~m}$ rakımdaki bir tepe üzerinde, yeni bir kale daha tespit edilmiştir (Harita 1). Bu kale; Ardahan-Damal karayolunun yaklaşık 650 m kadar doğusunda ve kuzey-güney yönünde akan Kura Nehri'nin 330 m doğusunda yer almaktadir.

Kalenin üzerinde yükseldiği tepe, esasında bir başka merkez ilçe yerleşimi olan Altaş Köyü'nün kuşbakışı 1,6 km güneyindedir; ancak Altaş Köyü mevkiinden bu alana Kura Nehri'nin varlığı sebebiyle ulaşılamamaktadır. Bunun yanında, kale kalıntısının güneyinde yer alan ve aynı zamanda Ardahan-Çıldır karayolunun kuzeyindeki arazi ve birkaç adet modern yapı, Ölçek Köyü sınırları içerisinde yer almaktadır; bu nedenle arkeolojik alan "Ölçek Köyü Kuzey Kalesi" olarak adlandırılmıştır. Ölçek Köyü sakinlerine ait bahsi geçen konutlar ile kale kalıntısı arasında 1,4 km kadar mesafe vardır.

Ölçek Köyü Kuzey Kalesi; doğu-batı doğrultusunda 53 m; kuzey-güney doğrultusunda 22 m'lik bir alanı kaplamaktadır. Kale; köşeleri yuvarlatılmış dikdörtgen planlı bir yapı olarak tanımlanabilir. Araştırma sırasında arazi seviyesinde kalenin tarihlenmesine yardımcı olabilecek türden herhangi bir küçük buluntu tespit edilememiştir. Bu nedenle kalenin kesin olarak hangi döneme ait olduğunu belirleyebilmek güçtür. Orta ve küçük boyutlu ve kaba işçilikli taşlarla kuru duvar tekniğinde inşa edilmiş duvarlar sadece 1-1,5 m yükseklikte yer yer korunabilmiştir. Yıkılan duvarlardan oluşan molozlar, duvarlar boyunca 3-5 m genişlikte araziye dağılmıştır. Kaleye giriş anlaşıldığı kadarıyla alanın doğu kenarından sağlanmaktaydı. Bu kenarda, ayrıca birkaç mekâna ait temel kalıntıları arazi üzerinde gözlemlenebilmektedir. Kalenin üzerinde yükseldiği tepeden özellikle batı ve güney yönlerinde kalan oldukça geniş bir arazi rahatlıkla gözlemlenebilmektedir. Hakim bir noktada olması, kalenin, Kura Nehri vadisinin güvenliği amacıyla kurulmuş, orta ölçekli bir karakol işlevine sahip olduğunu göstermektedir.

\section{Gölgeli Güneybatı Kalesi ve Yerleşimi}

2016 yılında Ardahan'ın merkez ilçe yerleşimlerinden Gölgeli Köyü çevresinde iki arkeolojik alan (Gölgeli Kalesi ve Gölgeli Yüksek Yayla Arkeolojik Alanı) tespit edilmişti (Patacı ve Laflı 2017: 115, fig. 4-5). 2017 y1lında bu köy çevresindeki araştırmalara devam edilmiştir. Gölgeli Köyü sakinlerinin yaylacılık faaliyetleri doğrultusunda kullandığı yüksek rakımlı arazide, hemen batı kenarında bir yerleşim alanı ile birlikte yeni bir Demir Çağı kalesi tespit edilmiştir. Bu alan, Gölgeli Köyü'nün güneybatısında, Ardahan-Kars karayolunun batısındaki köye ait 
araziden 3,6 km uzaklıkta yer almaktadır (Patacı 2019, 109-110, çiz. 1, res. 1-8) (Harita 1).

Yukarıda bahsedilen ve Gölgeli Köyü'nün hemen batısında yer alan diğer kalenin varlığından ötürü, bu yeni kale ve çevresindeki kalıntılar Gölgeli Güneybatı Kalesi ve Yerleşimi olarak adlandırılmıştır. Buradaki mimari kalıntılar, kuzeybatı-güneydoğu doğrultusunda konumlanmaktadır. Kale; kayalık bir tepe üzerine ve arazi koşullarına göre inşa edilmiştir (Çizim 1). Kalenin üzerinde yükseldiği tepe, 2287 ile 2299 m rakımları arasındadır. Kale, savunma duvarı göz önüne alındığında kuzeybatı-güneydoğu doğrultusunda $85 \mathrm{~m}$ ve güneybat1kuzeydoğu doğrultusunda 58 m'lik bir alanı kaplamaktadır. Kalenin güneydoğu terasındaki mekanlar da buna eklendiğinde güneybat1-kuzeydoğu doğrultusundaki maksimum uzunluğu 83 m'ye kadar çıkmaktadır. Kalenin batı kenarındaki yerleşim alanının ölçüleri kuzey-güney yönünde $78 \mathrm{~m}$ ve doğu batı doğrultusunda ise 70 m'dir. Kale ve yerleşim ile birlikte tüm arkeolojik alan 170 × 85 m boyutlarında bir araziyi kaplamaktadır.

Gölgeli Güneybatı Kalesi; genel olarak orta ve küçük boyutlu ve az işçilikli taşlarla kuru duvar tekniğinde inşa edilmiştir. Polygonal, dikdörtgen ve kare formlu bazalt taşlar inşa malzemesi olarak kullanılmıştır. Kale; kuzey ve güney olmak üzere iki alana sahiptir. Çokgen planlı kuzey alanın boyutları maksimum 45 x 40 m'dir (Resim 1). Kalenin batı ve doğu kenarları farklı seviyelerde teraslanmıştır. Doğu terasta, üç adet dörtgen planlı mekâna ait duvarlar temel seviyesinde gözlemlenmektedir. Kale duvarları genel olarak 1,40 m civarında bir kalınlığa sahiptir. Duvarların maksimum korunan yükseklikleri $2,5 \mathrm{~m}$ ilâ $3 \mathrm{~m}$ arasında değişmektedir.

Gölgeli Güneybatı Kalesi'nin hemen batısındaki arazi büyük olasılıkla mevsimlik bir yayla yerleşimi olarak kullanılmış olmalıdır. Yukarıda bahsedildiği üzere 78 x 70 m ölçülerindeki bu yerleşim alanında dikdörtgen ve kare planlı çok sayı mekânı temel kalıntıları arazi seviyesinden rahatıkla gözlemlenebilmektedir. Yüksek rakımlı bu arkeolojik alandaki bir kale ve bir yerleşime dair kalıntılar, Ardahan'da daha çok mevsimlik/geçici amaçla kullanılmış bazı arkeolojik alanları anımsatmaktadır. Bu arkeolojik alanlardan bir tanesi, Hanak ilçesinin Çayağzı yerleşimi yakınlarındaki Ziyaret Kale'dir. Ziyaret Kale'de de bir savunma yapısının kenarındaki arazinin yerleşim olarak kullanılmış olduğu bilinmektedir (Köroğlu 1998, 136-137). Ancak Ziyaret Kale'de Tunç Çağı çanak çömlek buluntuları Demir Çağı buluntularına göre daha yoğun görülmektedir. Ardahan'daki dağlık arazilerde bu tip arkeolojik alanlar yer almaktadır. Bölgenin Erken Tunç Çağı'ndan geç dönemlere değin değişmeyen yaşam biçimi olan hayvancılık faaliyetleri doğrultusunda oluşturulan bu yerleşimlerin askeri yapılar ile korunulmaya çalışıldığı, yaylacılık faaliyetleri yapılan arazilerin bu tip savunma yapılarıyla güvenliğinin sağlandığı anlaşılmaktadır. Son yıllarda tespit edilen bu arkeolojik alanlar görüşümüzü daha da belirginleştirmiştir.

Gölgeli Güneybatı Kalesi'nin hemen yanındaki yerleşimden geriye kalan yapı kalıntıları, buradaki mekanların küçük ve orta boyutlu taşlarla kuru duvar tekniğinde inşa edildiğini göstermektedir. Mekanlar arasından nispeten daha iyi 
korunmuş üç örneğin boyutları 8,5 x 6 m; 9,8 x 9 m ve 11 x 9 m'dir. Mekanlar en fazla $90 \mathrm{~cm}$ yükseklikte korunabilmiştir. Yapılardan bir tanesinden ölçülebilen duvar kalınlığı 1 m'dir. Yerleşim alanının çeşitli noktalarında kaçak kazı çukurları tespit edilmiştir. Tüm arkeolojik alanda ve ayrıca bu çukurların atım topraklarının üzerinde gözlemlenen çanak çömlek buluntuları Demir Çağı ağırlıklı olmak üzere Tunç Çağı'ndan Demir Çağı içlerine kadar çeşitlilik gösterir (Resim 2). Tunç Çağı çanak-çömlek parçalarına bakıldığında çarkta yapıldıkları anlaşılmaktadır; ancak bunlardan bazıları Kura-Aras Kültürü kaplarının devamı olarak dış yüzeyleri siyah (birkaç tanesi parlak siyah) renklidir ve depolama kapları sayıca daha yoğun tespit edilmiştir. Diğer çanak çömleklerde gri yahut grimsi kahverengi tonlarındaki monokrom kap parçaları yoğunluktadır. Bunlar genel olarak, gevşek dokulu, taşçık, kireç ve organik katkılı, orta ve düşük derecede pişmiş kalın cidarlı kaplardır. Kap parçalarının iç yüzeylerinde, birkaç basit kazıma bezemeli (birbirine paralel yatay çizgi bezemeli) olanlar haricinde bezeme tespit edilmemiştir. Geç Tunç ve Erken Demir Çağı çanak çömlekleri her ne kadar çarkta yapılsalar da bunların da genel olarak kaba ve özensiz imal edilmiş oldukları gözlemlenmektedir; fakat tespit edilenlerin sadece arazi yüzeyinde gözlemlenenlerden ibaret oldukları ve bu çanak çömleklerin arkeolojik alanın esas çanak çömlek karakterini yansıtmayabileceği de unutulmamalıdır. Demir Çağı çanak çömlekleri, açık sarıdan koyu turuncu ve kırmızıya yahut kırmızımsı kahverengiye değişen tek renkli, açkılı ve genel olarak pürüzsüz yüzeyli hem kapalı hem açık kap parçalarından oluşmaktadır. Form olarak ufak ve orta boyutlu çanaklar, tabak olması gereken birkaç parça ve daha özensiz ve kaba çömlekler, mutfak kapları grubunu oluşturur. Hamur yapısında siyah ve beyaz taşçık, yoğun kireç ve az miktarda organik ve mika katkısı görülmektedir. Çanak çömleklerin genelinde iç yüzeydeki birkaç basit kazıma bezemeli olanlar haricinde bezeme öğesi bulunmamaktadır. Perdahlı sarı ve kırmızı monokrom ince cidarlı kapların Doğu Anadolu'da görülen M.Ö. 7.-5. yüzyıllar çanak çömlekleri ile benzer oldukları düşünülse de bu tipteki parçaların diğer bölgelerdekilerle karşılaştırılmasının henüz araştırma ekibimizce yapılmamış olması sebebiyle detaylı bir veri sunabilmek şu an için mümkün değildir. Sadece Ardahan açısından bakıldığında ise bu tipteki kapların ilin daha çok güneyinde, Göle ilçesinde tespit edildiğini söylemek mümkündür. Gölgeli Güneybatı Kalesi ve Yerleşiminin M.Ö. II. binyıl içlerinde kurulduğu, ancak Demir Çağı'nda da faal olduğu tarafimızca düşünülmektedir. Bu alanda tespit edilen en geç çanak çömlek buluntular ise M.Ö. 7. ve 5. yüzyıllar arasına tarihlenebilecek türdedir. Elbette alanın daha detaylı tarihlendirilebilmesi için arkeolojik bir kazıya ihtiyaç vardır.

\section{Beşiktaş Kalesi, Yerleşimi ve Kurgan Mezarları}

2017 yılı araştırmaları sırasında tespit edilen en önemli arkeolojik alanlardan biri, il merkezinin karayolu ile $43 \mathrm{~km}$ güneydoğusunda yer alan ve Hasköy Bucağı'na bağlı olan Beşiktaş Köyü’ndedir. Köyün hemen kuzeybatısında, 
deniz seviyesinden $2291 \mathrm{~m}$ yükseklikteki Ziyaret ${ }^{1}$ adlı bir tepenin zirvesinde bir kale ile bu kaleye ait yapıların temel kalıntıları ve kurgan mezarlar tespit edilmiştir (Harita 1).

Kale; kuzey-güney yönünde $210 \mathrm{~m}$ ve doğu-batı doğrultusunda $133 \mathrm{~m}$ boyutlarındadır. Bu kalede iç ve dış olmak üzere iki ayrı sur duvarı vardır (Çizim 2; Resim 3). Kale; dış ve iç duvarlar arasında kalan geniş bir alan ve iç duvarın kapladığı daha küçük boyutlu ikinci bir alan olmak üzere ikili bir savunma sistemine sahiptir. İç surların kuzeybatı ve güneybatı köşelerinden dış duvara bağlanan iki diyagonal duvar sırası bulunmaktadır. Arkeolojik alanın batı kenarında kuzey-güney yönünde kaleye ait ayrı bir bölümmüş gibi uzanan ancak diğer duvar sıralarına oranla çok daha basit bir yapıda diğer bir duvar sırası daha göze çarpmaktadır. Bu duvar ile dış ve iç duvarları birleştiren diyagonal duvarlar arasında kalan kısım, arkeolojik alanın batı kenarında üçüncü bir alan meydana getirmektedir. İç duvarın kuzey kenarının doğu-batı doğrultulu bir duvar ile ayrı bir bölüme ayrılması da hesap edildiğinde tüm arkeolojik alanın dört ayrı alana ayrıldığ anlaşılmaktadır. Beşiktaş Kalesi; orta ve küçük boyutlu taşlarla kuru duvar tekniğinde ve kuzey-güney yönünde, üzerinde yükseldiği tepenin arazi koşullarına göre inşa edilmiştir. Kaleye ait iç ve dış duvarlar büyük ölçüde tahrip olmuştur ve duvarlardan arta kalan taş yığınları birkaç metre genişlikte kale boyunca araziye dağılmıştır. Ancak yer yer in situ duvarlar da takip edilebilmektedir. Savunma duvarlarının kalınlıkları 2 m civarındadır. Korunan duvarlar genel olarak temel seviyesindedir. Yukarıda bahsedildiği üzere kale 4 ayrı alana sahiptir. İç ve dış duvarlar arasında kalan birinci alanda en az 43 mekâna ait yapı kalıntısı ve kurgan olması muhtemel bir kalıntı yer almaktadır. İç duvar içerisindeki ikinci alanda, yani iç duvarın güney alanında, 18 mekâna ait yapı kalıntısı ve kurgan olması muhtemel bir kalıntı vardır. Kalenin doğu kenarını oluşturan 3. alanın kuzeydoğusunda ise duvara bitişik inşa edilmiş bir mekâna ait kalıntı daha yer alır ve kaledeki mekân kalıntısı sayısı gözlemlenebildiği kadarıyla en az 62'dir (Çizim 2). İç duvarın kuzey bölümünü oluşturan dördüncü alanda ise herhangi bir mimari yapı kalıntısı tespit edilmemiştir. Kalenin içerisindeki tüm mimari yapılar arazi seviyesinde ve oldukça kötü durumda korunmuştur.

Kalenin 10,5 m güneyinde ve 6,5 m çapında hemen hemen yuvarlak planlı bir kurgan vardır (Resim 4). Bu kurganın merkezinde bir kaçak kazı yapıldığı tespit edilmiş ve mezarın tahrip edildiği gözlemlenmiştir. Ufak boyutlu kurganın arazi seviyesinden yüksekliği maksimum $50 \mathrm{~cm}$ 'dir. Boyutları açısından Ardahan açısından bilindik bir mezar çeşidi olan bu kurgan üzerine detaylı bir değerlendirme yapabilmek tahrip olması nedeniyle mümkün değildir. Ancak daha önceki yıllarda Kemalettin Köroğlu tarafından tespit edilen Çıldır ilçesi Kurtkale kurganları ile benzer olduğu anlaşılmaktadır (Köroğlu 2000: 2-11). Ardahan Kurganları, Akçakale Adası Kurganı haricinde genel olarak anıtsal özelliğe sahip olmayan, 5-7 metrelik bir çapa sahip, arazi seviyesinden pek yüksek olmamak şartı

\footnotetext{
${ }^{1}$ Ardahan'da arkeolojik kalıntılara sahip bu tipteki tepelerin bir kısmı, Ziyaret adıyla anılmaktadir.
} 
ile tamamı taş dolgu ile doldurulmuş ve ufak boyutlu mezar bölmesinin mezarın merkezinde ve 1-1.5 m arasında değişen toprak altı seviyede yer aldığı basit mezar tipleridir. Kare veya dikdörtgen planlı mezar bölmelerinin üzerinin kısmen düzgün kesme taşlarla kapatıldığı da bilinmektedir. Ayrıca Ardahan'ın merkez ilçesindeki Kartalpınar Kalesi ve Mezarlığı'nda da Doğu Anadolu Arkeolojisi adına oldukça önemli ve büyük boyutlu bir başka buluntu grubu daha 2014 yılında tarafımızca tespit edilmiştir (Patacı ve Laflı 2019: 261; Patacı ve Laflı 2016: 284-285; Patacı vd. 2017: 181-182). Bu arkeolojik alanda kurgan tipinde mezarların dişında Erken Demir Çağı'nın üzeri kyklopik taşlarla kapatılmış mezar tiplerinden daha basit dikdörtgen ve kare planlı taş mezarlara kadar değişen mezarlar da kurganlar haricinde bulunmaktadır. Yaptığımız araştırmaların sonuçlarına göre Kartalpınar'da kaçak kazı ile tahrip edilmiş 16 mezarın haricinde kuzey-güney yönünde 370 m'lik bir alanda 118 mezarın olduğu anlaşılmaktadır. Ne yazık ki bu arkeolojik alan günden güne insan eliyle defineciler tarafindan tahrip edilmektedir. Doğu Anadolu kurganlarının genel özellikleri açısından referans alınması gereken bazı önemli yayınlar ise Aynur Özfırat tarafindan kaleme alınmıştır (Özfirat 2000: 67, 71 ve 77; Özfirat 2002: 343-371; Özfirat 2009a: 635-674; Özfirat 2009b: 233247; Özfirat 2010: 42-43; Özfirat 2014: 209-226).

Beşiktaş’ta bahsi geçen mimari kalıntılar dışında kalenin güneydoğu kenarından başlayıp yine güneydoğu istikametinde en az $200 \mathrm{~m}$ kadar ilerleyen bir duvar kalıntısı daha arazi seviyesinde az da olsa gözlemlenebilmektedir. Kalenin güneyi ve doğusunda kalan arazinin hayvancılık faaliyetleri doğrultusunda kullanılmış olması muhtemeldir. Hem güneydoğu istikametinde uzanan ve $200 \mathrm{~m}$ uzunluktan fazla devam eden bu duvar kalıntısı hem de birden çok savunma duvarına sahip oluşu ve ayrıca savunma duvarlarının içindeki alanda konut yapısı olması gereken çok sayıda mekâna ait kalıntılar Beşiktaş Kalesi'nin Çıldır'ın Akçakale köyü yakınlarındaki Senger Tepe yerleşimi ile benzer özelliklere sahip olduğunu göstermektedir. Her iki alanda da Tunç Çağı'ndan Demir Çağı içlerine kadar tarihlenebilecek türden çanak çömlek buluntusu gözlemlenebilmektedir. Beşiktaş Kalesi'nin içinde tespit edilen çanak-çömlek sayısı oldukça az olup tespit edilenler arkeolojik alanın yakın çevresinden ele geçmiştir (Resim 10). Çanakçömlek parçalarının büyük kısmı Demir Çağı'na ait olup II. binyıl seramikleri azınlıktadır. Ancak bu parçalar sadece yüzeyde tespit edilebilenler olduğu için alanın hangi dönemde daha yoğun kullanıldığını kestirebilmek henüz mümkün değildir. II. binyıl mat siyah monokrom ve çark yapımı çanak-çömlekleri az sayıda ele geçtiğinden bunlar üzerine detaylı bir yorum yapılamamaktadır; ancak tespit edilenler Gölgeli Güneybatı Kalesi ve Yerleşiminde ele geçenlerle benzerdir. II. binyıl örnekleri arasında tarak bezemeli bir Geç Tunç Çağı parçası dışında bezemeli olan bir buluntu yoktur (Resim 10). Demir Çağı seramikleri Beşiktaş Kalesi'nin kuzeyindeki yakın çevrede tespit edilmiştir. Bunlar da genel itibariyle monokrom olup, yüzeyleri kırmızıdan açık sarıya değişmektedir. İnce cidarlı bazı örneklerde geometrik kazıma bezemeler gözlemlenmiştir. Ancak Beşiktaş çanakçömlek buluntularının genelinde kaba ve özensiz bir üretim dikkat çekmektedir. 
Beşiktaş Kalesi'nin II. binyıldan Demir Çağı içlerine kadar kullanılmış olması muhtemeldir. Ancak Demir Çağı çanak-çömleklerinin alanın içinden değil kuzeyindeki yakın çevresinden ele geçtiğini vurgulamak gerekir. Bu arkeolojik alanın, sur duvarları ile güçlendirilmiş mevsimlik bir yüksek yayla (ya da tepe) yerleşimi olması gerekmektedir. Burası, ayrıca kurgan kalıntılarından anlaşıldığı kadarıyla mezarlık olarak da kullanılmıştır. Bu buluntu alanının detaylı bir tarihlendirmesini yapabilmek için basit bir yüzey araştırmasından fazlasına yani arkeolojik bir kazıya ihtiyaç vardır.

\section{Çobanköy Kalesi ve Yerleșimi}

Göle ilçe merkezinin karayolu ile $26 \mathrm{~km}$ kuzeydoğusunda yer alan Çobanköy birbirine oldukça yakın iki ayrı arkeolojik yerleşim alanına sahiptir (Patac1 2019: 110-111). Çobanköy'ün batı sınırından 700 m kadar ileride, köyün kuzeybatısındaki bir tepe üzerinde iç ve dış surlara sahip bir kale yer almaktadır (Harita 1). Kale ve yerleşimden oluşan arkeolojik alanın ölçüleri 250 x 85 m'dir. Kalıntıların üzerinde yer aldığı tepe 2188-2200 m arasındadır.

Çobanköy Kalesi kuzeydoğu-güneybatı doğrultusunda konumlandırılmıştır. Arazi koşullarına paralel olarak inşa edildiği anlaşılan kalenin iç ve dış surları ne yazık ki büyük oranda tahrip olarak temel seviyesinde korunmuş ya da duvar örgüsünden geriye sadece arazi üzerine dağılmış olan moloz yığı̆ları kalmıştır. Birden fazla doğal ve geniş teraslara sahip arkeolojik alanda yine de gözlemlenebildiği kadarıyla temel seviyesinde yer yer korunabilmiş duvarların 1,5$2 \mathrm{~m}$ civarında bir genişliğe sahip olduğu anlaşılmaktadır. Kalenin iç suru, arkeolojik alanın batı kenarında yer almaktadır. İç duvar uzunluğu kuzeydoğugüneybatı yönünde maksimum $72 \mathrm{~m}$; genişliği ise $46 \mathrm{~m}$ civarındadır. İç duvar alanının merkezinde biri dikdörtgen $(5,40 \mathrm{x} 4,80 \mathrm{~m})$ diğeri dıştan beşgen içten dörtgen planlı $(7,30 \times 6,90 \mathrm{~m})$ iki adet yapı tespit edilmiştir. Aslında temel seviyesinde korundukları anlaşılan bu yapılar, günümüze yakın bir dönemde Çobanköy sakinleri tarafindan da hayvancılık faaliyetleri doğrultusunda basit kuru duvar tekniğinde yükseltilmiştir. Arazi seviyesinde gözlemlenebilen alt sıra duvar örgüsünden anlaşıldığı kadarıyla her iki yapı küçük ve orta boyutlu taşlarla kuru duvar tekniğinde inşa edilmiştir.

Arkeolojik alanın kuzeyinde ve kuzeydoğusunda bazı mekanlara ait yapı kalıntısı izleri arazi seviyesinde gözlemlenebilmektedir. Bunun yanında, kalenin kuzeybatı dış surunun hemen iç bitişiğine inşa edilmiş en az 10 mekân yan yana ve yine temel seviyesinde korunabilmiştir. $\mathrm{Bu}$ mimari birimlerin hangi işlevde kullanıldıklarını tam olarak kestirebilmek kazı yapılmaksızın mümkün değildir. Ancak savunma duvarları haricinde, arkeolojik alanın doğu, kuzeydoğu ve kuzeybatısında gözlemlenen yapı kalıntılarının konut kalıntıları olması mümkündür. Kalenin doğusunda, iç ve dış surlar arasında kalan alanda; 1,70 x 2,00 $\mathrm{m}$ boyutlarında, muhtemelen bir mezar olması gereken bir kalıntı vardır. Sınırlarının orta ve ufak boyutlu taşlarla oluşturulmuş olduğu anlaşılan bu mezarın kaçak kazı sonucu tahrip edildiği gözlemlenmiştir. Mezar olması gereken bir başka kalıntı, iç surun hemen güneydoğu ucunda yer alır. 2,80 x $1,60 \mathrm{~m}$ boyutlarında 
dikdörtgen planlı bu mezar, diğeri gibi yine tahrip durumdadır. Çobanköy Kalesi'nde gözlemlenen çanak çömlek buluntuları Geç Tunç Çağı'ndan Demir Çağı içlerine ve hatta Orta Çağ'a değin çeşitlilik göstermektedir. Çark yapımı ve siyah mat zeminli monokrom II. binyıl çanak-çömlekleri arkeolojik alandaki en erken örneklerdir. Geç Tunç Çağı örneklerinden tarak bezemeli olanlar sayıca çoğunlukta olup Ardahan'da Ölçek, Kocaköy ve Hasköy'deki arkeolojik alanlarda da takip edilen tipik örneklerdir. Erken Demir Çağı'na ait gri monokrom çömlek parçaları ve geometrik kazıma bezemeli örneklerden dönemin daha geç safhalarına ait kırmızı astarlı çanak-çömlek parçalarına kadar değişen çok sayıda buluntu arkeolojik alanda tespit edilmiştir.

\section{Çobanköy Höyüğü}

Çobanköy'ün hemen kuzeyinde inşa edilmiş olan bir su deposunun üzerinde yükseldiği tepenin doğu kısmının bir höyük olduğu anlaşılmaktadır. Köy merkezi ile bu höyüğün arasında 400-500 m'lik; höyügü̈n kuzeybatısındaki Çobanköy Kalesi ve Yerleşimi ile höyük arasında ise 1,15 km'lik bir mesafe vardır (Resim 5). Her iki arkeolojik alan da birbirini görür şsekilde konumlanmakla birlikte, aralarında 90-100 m'lik bir yükseklik farkı vardır. Höyük; deniz seviyesinden 2101 ilâ $2109 \mathrm{~m}$ arasındaki rakımlarda yer alır. Bu özelliği ile Ardahan Bölgesindeki düşük rakımlı ender arkeolojik alanlardan biridir.

Höyüğün zirvesi, doğu-batı doğrultusunda 66 m, kuzey-güney yönünde 61 $m$ boyutlarında olan üçgen formlu bir teras şeklindedir. Höyüğün kuzey eteğinde, doğu-batı doğrultusunda birkaç metre uzanan bir duvar kalıntısı vardır. Temel seviyesindeki bu duvarın kuru duvar tekniğinde inşa edildiği anlaşılmaktadır. Teras üzerinde ne yazık ki 20 civarında kaçak kazı çukuru olduğu tespit edilmiştir. Bu alanın uzun zamandır insan eliyle tahrip edilmekte olduğu anlaşılmaktadır. Kaçak kazı çukurlarının bir kısmı incelenmiş ve höyügün bazı noktalarında mezarlar olabileceği anlaşılmıştır. Kaçak kazı çukurlarında yaptığımız incelemeler sırasında M.Ö. II. biny1l içlerinden M.Ö. 8.-5. yüzyıllara kadar farklı tarihlere ait bol miktarda çanak çömlek parçalarının olduğu gözlemlenmiştir. Özellikle Geç Tunç Çağı'na ait kalıp açkı yöntemi ile bezenmiş çanak-çömlek parçaları buluntular arasında dikkat çeken örneklerdendir (Resim 14). Bu tipteki çanak-çömlek buluntularının benzerleri Kartalpınar Mezarlığı'nda da tespit edilmiştir (Patacı ve Laflı 2015: fig. 16). Erken Demir Çağı çanak-çömlek buluntularının kazıma geometrik bezemelere sahip olduğu görülmektedir. Demir Çağı içlerine ait örnekler ise Çobanköy Kalesi'nden daha fazla miktardadır. Şu an için höyük olarak tanımladığımız bu arkeolojik alanın bir bölümünün mezarlık olarak da kullanılmıs olduğu anlaşılmaktadır. Alanın işlevinin arkeolojik bir kazı ile aydınlatılması gerekmektedir; ne var ki bu gerçekleşene kadar buluntu yerinin tamamen tahrip olmas1 muhtemeldir. 


\section{Kuzupınarı Kalesi ve Yerleşimi}

Kale; Göle ilçe merkezinin 26.7 km kuzeybatısındaki Kuzupınarı köyünün batısında, geniş bir ovaya bakan tepenin doğu ucunda yer almaktadır. 2170-2182 m rakımları arasındaki bu alan 2017 yılında tespit edilmiştir (Patacı ve Oral Patacı 2018: 18-20) (Harita 1-2)

Kuzeybat1-güneydoğu doğrultusunda konumlandırılmış olan kale; orta ve büyük boyutlu az işçilikli dikdörtgen, kare ve polygonal kesme taşlarla, kuru duvar tekniğinde inşa edilmiştir. Kalenin doğu kenarı, kayalık zemin üzerinde yükselmektedir. Kuzupınarı Kalesi, aynı bölge içerisinde yer alan Bellitepe-Batı Kulesi gibi, köşelerinde dışa doğru çıkıntı yapan yuvarlak planlı burçlara sahiptir (Çizim 3; Resim 6). Bu burçlar dışında, batı dış duvarının merkezinde ayrıca bir burç daha bulunur. Kalenin beden duvarları kuzey-güney yönünde $22.60 \mathrm{~m}$; doğubatı doğrultusunda 12.9 m'lik ölçülere sahiptir. Burçlar da hesap edildiğinde kalenin arazi üzerinde kapladığı alan 30 x 15.5 m'dir. Kuzupınarı Kalesi'nde duvar kalınlıkları $2.20 \mathrm{~m}$ ile $3.40 \mathrm{~m}$ arasında değişmektedir. Korunan duvar yükseklikleri maksimum $2.50 \mathrm{~m}$ ile $3.00 \mathrm{~m}$ arasındadır. Kuzey-güney doğrultusunda iki mekâna sahip kaleye giriş kuzeydoğu kenardan sağlanmaktadır. Buradaki kap1 genişliği $1.14 \mathrm{~m}$ ve yüksekliği $1.00 \mathrm{~m}$; kapı lento genişliği $1.90 \mathrm{~m}$ ve yüksekliği $40 \mathrm{~cm}$; giriş koridorunun korunan uzunluğu $3.47 \mathrm{~m}$; genişliği $1.38 \mathrm{~m}$ ve yüksekliği 1.10 m'dir. Kalenin girişinden kuzey mekanına ulaşılmaktadır. Bu mekânın ölçüleri 7.42 x 6.20 m'dir. Güney mekân ise 9.15 x 8.12 m ölçülerindedir. Kuzey ve güney mekanlar arasındaki geçit, yıkılan duvarlardan arta kalan moloz yığını sebebiyle tespit edilememiştir. Kalenin burçlarını oluşturan taşlar, beden duvarları taşlarından biraz daha büyük boyutludur ve burç duvarları beden duvarlarına oranla daha iyi korunmuş durumdadır.

Kuzupınarı Kalesi'nin batı ve güneybatısında, kale duvarlarının 8-9 m dışında, kuzey-güney yönünde uzanan ayrı bir duvar sırasına dair bir temel kalıntısı daha gözlemlenebilmektedir. Kalenin doğu kenarı, tepenin dik eğimli yamacının sınırında olduğundan bu bölgenin savunma açısından ekstra bir duvara ihtiyacı olmayacaktı; ancak kaleye batı yönünde rahatlıkla ulaşılabilir olması, buraya bir çevre duvarının inşa edilmesini gerektirmiş olmalıdır. Bu duvar kalenin batı kenarı boyunca uzanıyor ve aynı zamanda kalenin güney duvarının merkezinde, yani iki burç arasındaki beden duvarında sonlanıyordu. Bu bölgedeki bir başka önemli kalıntı kümesi, burada muhtemelen bir yayla yerleşimi olduğunu düşündürmektedir. Kalenin kuzey ve kuzeydoğusundaki arazi üzerinde iki ayrı yapı kalıntısı bulunmaktadır. İlk yapı kalıntıları kalenin hemen kuzey kenarının birkaç metre önünde başlayıp kuzey-güney istikametinde $30 \mathrm{~m}$ kadar yayılmaktadır. $\mathrm{Bu}$ yapı kalıntıları en az 10-12 kare planlı mekândan oluşmaktadır. Diğer mimari kalıntı grubu, kalenin 28 m kadar kuzeydoğusunda başlamaktadır. Bu kalıntılar da gözlemleyebildiğimiz kadarıyla yine en az 12 mekândan oluşmaktadır ve kuzeygüney doğrultusunda $25 \mathrm{~m}$ kadar uzanmaktadır.

Kuzupınarı Kalesi'nin güneyinde mezar olabilecek türden bir-iki ufak boyutlu kalıntı arazi seviyesinde görülmektedir. Ancak bu alanda aynı zamanda bazı kaçak kazı çukurları da tespit edilmiştir. Kalenin batısındaki arazide doğu-batı 
doğrultusunda $30 \mathrm{~m}$ civarında gözlemlenebilen bir kalıntı kümesi daha vardır ancak bu alan oldukça tahrip durumda olduğundan üzerinde detaylı bir yorumlama yapılması mümkün değildir. Tüm alanın boyutları kuzey-güney yönünde $100 \mathrm{~m}$; doğu batı doğrultusunda ise $60 \mathrm{~m}$ civarındadır. Kuzupınarı Kalesi ve yakın çevresinde yaptığımız incelemelerde az miktarda Demir Çağı ve Ortaçağ çanak çömlekleri gözlemlenmiştir. Kalede ve kalenin bulunduğu bölgede yer alan bir başka savunma yapısı Bellitepe-Batı Kulesi'nde tespit edilen çanak çömlek buluntuları ve ayrıca her iki yapının benzer mimari özellikleri, bizlere bu arkeolojik alanların Demir Çağı'nda kullanıldığını göstermektedir. 2016 yılı yüzey araştırması sırasında tespit edilen 'Köprülü Yüksek Yayla Arkeolojik Alanı da Kuzupınarı Kalesi'nin kuşbakışı 2,3 km kadar güneydoğusunda yer almaktadır ve her iki arkeolojik alan da birbirini görür vaziyette konumlanmaktadır (Patacı ve Laflı 2017: 115, fig. 12).

Kuzupınarı Kalesi'nin yaklaşık $170 \mathrm{~m}$ kuzeybatısında modern bir ağıl bulunmaktadır ve Kuzupınarı sakinlerinin burada yaz mevsimi süresince hayvancılık faaliyetlerinde bulunmak üzere çadırlarıyla kaldıkları görülmüştür. Esasında kalenin de yer aldığ 1 tepe binlerce yıldır bu faaliyetler doğrultusunda kullanılıyor olmalıdır. Kalenin özellikle kuzeyindeki mimari kalıntılar, buranın sadece askeri işlevde kullanılmadığını, aynı zamanda Demir Çağı içlerinde bir yerleşimin de burada var olduğunu göstermektedir. Büyük olasılıkla, orta boyutlu bir karakol işlevinde inşa edilmiş olması gereken bu kalenin asıl var olma sebebi, hem doğu-batı doğrultusunda uzanan geniş ovayı ve bu ovanın kuzeyinde aynı yönde uzanan Kura Nehri kolunu güvenlik altına almak hem de bölgedeki yerleşimlerin güvenliğini sağlamak olmalıydı. Kuzupınarı Kalesi'nin ve bu kalenin yakınlarında inşa edilmiş Bellitepe kulelerinin konumlandırılma özellikleri, Urartu kaleleri ile benzer özellikler sergilemektedir. Urartu kaleleri de tarımsal faaliyetlerin yapıldığ 1 geniş ovalara bakan tepelerin zirvesinde ve kayalık zemin üzerinde inşa edilmekteydi (Forbes 1983: 5; Çilingiroğlu 1997: 48). Ticaret yollarının, su kaynaklarının ve kentlerin güvenliği bu şekilde sağlanmaktaydı. Ayrıca savunma yapılarının yakın çevresindeki yerleşimlerden toplanan tarım ürünleri, kalelerin depolarında biriktirilmekteydi. Doğu Anadolu Bölgesi, Kuzeybatı İran ve Ermenistan topraklarında yayılım göstermiş çok önemli bir uygarlık olan Urartu Krallığı, mutlaka yakın çevresindeki yerel kültürleri de etkilemiş olmalıdır. Kesin olmamakla birlikte Kuzupınarı ve Bellitepe'de 2017 yılında tespit edilen bu arkeolojik alanların, Urartu Krallığı'nın askerî konumlanma geleneğinden etkilenilerek yerel otorite tarafindan inşa edildikleri düşünülebilir. $\mathrm{Bu}$ değerlendirmemizin ne kadar doğru olduğu, elbette kapsamlı arkeolojik araştırmaların sonuçları ile anlaşılacaktır.

\section{Bellitepe-Batı Kulesi}

Ardahan'ın Göle ilçesinde yer alan Bellitepe'nin 600/650 m kadar batısında, Bellitepe ve Yeleçli köylerini birbirine bağlayan karayolunun hemen 160 m kuzeyindeki fazlaca yüksek olmayan bir tepenin üzerinde yer alan bir kule, 2017 yılında tespit edilmiştir (Harita 1-2). 
Kare planlı kule; dört köşesinde dışa doğru çıkıntı yapan yuvarlak planlı birer burca sahiptir (Çizim 4; Resim 7). Bu mimari özelliği sebebiyle, Kuzupınarı Kalesi ile birlikte Ardahan'daki ünik savunma yapıları arasındadır. Ancak Kuzupınarı Kalesi'nin -adından da anlaşılacağı gibi- daha büyük boyutlu bir savunma yapısı olması sebebiyle Bellitepe-Batı Kulesi'nden ayrıldığını belirtmek gerekir. Buna rağmen kanaatimizce iki savunma yapısı da aynı dönemlerde inşa edilmiş olmalıdır. Zaten bu iki yapının birbirine karayolu ile $6,5 \mathrm{~km}$ ve kuşbakışı 4,7 km gibi yakın mesafede konumlanmış olması da aralarında bir ilişki olabileceğini bizlere göstermektedir. Her iki yapı da mimari özellikleri sebebiyle şu ana kadar karşılaştığımız savunma yapıları arasında ayrıca ele alınması gereken örneklerdir. Bu iki savunma yapısı dışında Bellitepe'nin doğusunda, bir diğer kule, yine 2017 yılı araştırmaları sırasında tespit edilmiştir. Bu bölgede, doğu-batı doğrultusunda uzanan Kura Nehri'ne bağlı derenin ve zirai faaliyetler için uygun olabilecek geniş ovanın varlığı, savunma yapılaşmasını etkilemiş olmalıdır. Dolayısıyla (çanak çömlek buluntuları ışığında) bu üç yapının Demir Çağı'nda belki de bu bölge üzerindeki kontrol edilmesi gereken bir yolun güvenliğinin sağlanması için kullanıldığını söylemek mümkündür. Kulede ve kulenin yakın çevresinde yapılan araştırmada az miktarda kırmızı renkli Demir Çağı malları ve genel olarak açik sarı renkli ve bezemesiz Ortaçağ seramikleri gözlemlenmiştir (Resim 8).

Bellitepe-Batı Kulesi, burçlar hesaba katılmadığında ve sadece beden duvarları değerlendirildiğinde kuzey-güney yönünde $14.4 \mathrm{~m}$ ve doğu-batı yönünde $14.2 \mathrm{~m}$ boyutlarındadır. Ancak dışa doğru çıkıntı yapan yuvarlak planlı burçlar bu ölçülendirmeyi değiştirerek, kuzey-güney yönünde $21.4 \mathrm{~m}$ ve doğu-batı doğrultusunda 18.6 m'lik bir alan içerisinde kulenin inşa edildiğini göstermektedir. Bunun yanında, temel seviyesinde korunabilmiş olan ayrı bir duvar sırası da yapıyı çevrelemektedir. Batı yönünde bu çevre duvarı ile kule arasında 5 ilâ $8 \mathrm{~m}$ arasında bir mesafe vardır. Kuzey yönünde bu mesafe 6 ilâ 9 m'ye çıkar. Güney yönünde ise çevre duvarı ile kule arasındaki mesafe $9 \mathrm{~m}$ ilâ $12 \mathrm{~m}$ arasında değişmektedir. Kulenin doğu kenarında çevre duvarı takip edilememektedir. Çevre duvarı ile birlikte savunma yapılaşmasının ölçüleri toplamda kuzey-güney yönünde 38 m'dir. Kulenin doğu kenarında en az dokuz mekâna ait temel seviyesinde korunmuş bir kalıntı kümesi daha yer almaktadır. Aynı zamanda, kulenin güney ve güneydoğu kenarlarında da yan yana 7-8 mekâna dair izler arazi seviyesinde zorlukla da olsa gözlemlenebilmektedir. Ardahan coğrafyası açısından 2036-2046 m gibi düşük rakımlar arasında yer alan arkeolojik alanın doğu-batı istikametinde kapladığı alan $70 \mathrm{~m}$; kuzey-güney yönünde kapladığı alan ise yaklaşık 60 m'dir. Bellitepe Batı kulesi orta ve büyük boyutlu taşlarla kuru duvar tekniğinde inşa edilmiştir. Yapının duvar kalınlıkları $2.77 \mathrm{~m}$ ilâ $2.90 \mathrm{~m}$ arasında değişmektedir. Korunan duvar yükseklikleri $1.5 \mathrm{~m}$ ilâ $2 \mathrm{~m}$ arasındadır. Kulenin girişi, yapının güney kenarındadır (Resim 9). Güney cephenin merkezinde $1 \mathrm{~m}$ genişliğinde bir kapı açıklığ 1 vardır. Giriş, $1.16 \mathrm{~m}$ alınabilen yüksekliğe sahiptir. $1.30 \mathrm{~m}$ genişlikteki giriş koridoru, yapının içine, kuzeye doğru 3.40 m kadar uzanmaktadır. Kuzey-güney yönünde 10 
m ve doğu-batı doğrultusunda 9.40 boyutlarındaki kule yapısı mimari açıdan bir mekândan oluşmaktadır.

\section{Bellitepe-Doğu Kulesi ve Eskiçağ Ağılı}

Bellitepe'nin 2,2 km doğusunda, modern karayolunun yaklaşık $500 \mathrm{~m}$ kuzeyinde ve yüksekçe bir tepenin 2129-2138 m rakımları arasındaki güney yamacında, diğer bir kule yapısı yer almaktadır (Harita 1-2). Kuzeydoğu-güneybatı doğrultusunda konumlandırılmış olan ve hemen hemen dikdörtgen bir plana sahip Bellitepe-Doğu Kulesi ne yazık ki büyük oranda tahrip durumdadır. Güneybatı kenarı dışında, köşeleri yuvarlak açılı olan yap1, kuru duvar tekniğinde, arazi koşullarına göre inşa edilmiştir (Çizim 5). Orta ve büyük boyutlu, az işçilikli taşlar yapının inşasında kullanılmıştır. Yapının boyutları 14.30 x 10.50 m'dir. Duvar kalınlıkları, $2.30 \mathrm{~m}$ civarındadır. Duvar yükseklikleri yapının kuzey kenarında maksimum 1-1.5 m civarında korunmuştur.

Bellitepe-Doğu Kulesi'nde ve yapının bulunduğu mevkideki incelemelerimizde az miktarda Geç Tunç Çağ1, Demir Çağı ve Ortaçağ çanakçömleği gözlemlenmiştir. Geç Tunç Çağı örnekleri kalıp açk1 yöntemi ile yapılmış mallar ve tarak bezemeli kap parçalarından oluşmakta, Demir Çağı çanakçömlekleri kırmızı astarlı birkaç örnekten ve Ortaçağ seramikleri ise açık sarı astarlı ve kazıma bezemeli az sayıda parçadan ibarettir. Yapı, doğu, güney ve kuzey yönlerinde kilometrelerce genişlikteki arazinin rahatlıkla gözlemlenebileceği bir mevkide konumlandırılmıştır (Resim 10). Yapının $700 \mathrm{~m}$ kadar güneyinde, doğu-batı doğrultusunda uzanan Kura Nehri'ne bağlı bir kolun varlığı, Demir Çağı'na ait olması gereken bu gözetleme kulesinin en önemli inşa nedeni olmalıdır. Gözetleme kulesinin inşa edildiği tepenin $2200 \mathrm{~m}$ rakımlı zirvesinde, bir ağıl yapısına ait olduğunu düşündüğümüz oldukça tahrip olmuş bir kalıntı da yer almaktadır. Bu ağıl ile Bellitepe-Doğu Kulesi arasında $185 \mathrm{~m}$ kadar kısa bir mesafe vardır. 85 x 65 m ölçülerinde ve yuvarlak planlı olduğu anlaşılan ağılda korunabilmiş bir duvar kalıntısı yoktur. Yerli halkın yıkılan duvarlardan inşa ettiği, kuru duvar tekniğinde $1 \mathrm{~m}$ yükseklikte örülmüş modern bir duvar, alanı çevrelemektedir. Ağılın yıkılan duvarına ait moloz taş yığınları, alan boyunca birkaç metre genişlikte arazi üzerine dağılmıştır. Ağıll çevresinde herhangi bir küçük buluntu tespit edilememiştir.

\section{Kotanlı Yerleșim Alanı}

Kotanlı Köyü, Çıldır ilçe merkezinin 14 km kuzeybatısındadır. Bu köyün kuşbakış1 770 m güneydoğusunda bir yerleşim alan1 2017 yılında tespit edilmiştir (Harita 1). Kuzey-güney doğrultulu bir vadinin merkezinde, Hidıkur Deresi'nin batı, kuzey ve doğu yönlerinden sardığı Senger Tepe adlı bir yarımadanın zirvesinde yer alan bu alana olumsuz hava koşulları ve Hıdıkur Deresi'nin aşılamaması sebebiyle ulaşılamamıștır. Yine de bu alanın boyutlarını ve işlevini tespit edebilmek amaciyla olabildiğince yakınlaşıp belgeleme yapılmaya çalışılmıştır. 
Kotanlı yerleşimi; 71 x 68 m'lik bir alanı çevreleyen bir duvar sırasından oluşmaktadır. Bu duvar sırası anlaşıldığ 1 kadarıyla günümüze kadar korunamamış, yıkılan moloz yığınları arkeolojik alan boyunca birkaç metre genişlikte araziye dağılmıştır. Kotanlı köyü sakinleri tarafından bu alan günümüzde bir ağıl olarak kullanılmaktadır. Her ne kadar kuru duvar tekniğinde 1-1,5 m civarında yükselen duvarlar gözlemlenebilmekteyse de bu duvarların daha sonra Kotanlı köyü sakinlerince oluşturulmuş olduğu anlaşılmaktadır. Arkeolojik bir kazı yapıldığı takdirde yapı temelinin en azından sonradan yükseltilmiş bu duvarların altından çıkabileceği düşüncesindeyiz. Arkeolojik alana ulaşılamadığından yarımadada küçük buluntu tespit edebilme şansımız olmamıştır. Dolayısıyla arkeolojik alanın hangi döneme ait olduğunu tespit edebilmek mümkün olmamıştır. Sadece genel mimarlık özelliklerinden yola çıkarak buranın eski bir yerleşim alanı olduğu ileri sürülebilir. Bunun yanında arkeolojik alanın hangi işlevde kullanılmış olduğunu kesin olarak belirleyebilmek de detaylı bir inceleme yapılamadığı için mümkün değildir. Olasılıklardan iki tanesi, buranın hayvancılık faaliyetleri için oluşturulmuş bir tür ağıl ya da bir savunma yapısı olduğuna yöneliktir.

\section{Sulakyurt Demir Çağı ve Ortaçağ Çanak Çömlek Buluntu Alanı}

İl merkezinin 9,5 km kuzeybatısında yer alan Sulakyurt Köyü'nün doğusundaki bölge 2017 yılında araştırılmıştır. Sulakyurt'un karayoluyla 5,1 km güneydoğusunda, günümüzde tarımsal faaliyetlerin yapıldığı bir arazi üzerinde, Demir Çağı'na ve Ortaçağ'a ait çok sayıda çanak çömlek parçasına denk gelinmiştir (Harita 1). 1805-1810 m rakımları arasındaki bu alan, modern bir su deposunun hemen 35-40 m kadar güneydoğusunda, Ardahan-Artvin karayolunun ise $1 \mathrm{~km}$ kuzeyinde yer almaktadır. Kuzey-güney yönünde $250 \mathrm{~m}$ ve doğu-batı doğrultusunda maksimum $110 \mathrm{~m}$ ölçülere sahip arazi üzerinde, ağıllıklı olarak Demir Çağı çanak çömlekleri ve daha az miktarda Ortaçağ seramiği gözlemlenmiştir. Demir Çağı çanak-çömlekleri sarı, kırmızı ve grimsi kahverengi olmak üzere monokrom mallar olup hamur yapılarında siyah ve beyaz taşçıklar, kireç, mika ve organik katkı gözlemlenmiştir. İnce cidarlı mutfak kapları çoğunlukta olup büyük boyutlu depolama kaplarına ait sadece birkaç parça tespit edilebilmiştir. Ortaçağ seramik buluntularında dikkat çeken birkaç örneğin Kars ili, Ani kentindeki kırmızı astarlı Ortaçağ seramikleri ile benzer olmalarıdır. Bu tipteki örnekler esasında daha çok Ani kentine has olup İ.S. 13. yüzyıla kadar kullanılmaya devam edilmiş olmalıdırlar. Sulakyurt’taki bu buluntu alanında sadece küçük buluntuların gözlemlenmesi ve herhangi bir mimari kalıntının saptanamaması sebebiyle alanın işlevi üzerine sağlıklı bir yorum getirebilmek mümkün değildir.

\section{Doğankaya Demir Çağı ve Ortaçağ Çanak Çömlek Buluntu Alanı}

Doğankaya köyü Çıldır ilçe merkezinin $21 \mathrm{~km}$ doğusunda yer almaktadır. Bu köyün hemen kuzeydoğu kenarında Demir Çağı ve Ortaçağ’a ait çanak çömlek parçaları tespit edilmiştir (Harita 1). Çanak çömlek buluntularının haricinde alanda herhangi bir mimari buluntu gözlemlenememiştir. Tespit edilen çanak-çömlek 
sayısı oldukça azdır; bunlardan Demir Çağı'na ait olanlardan bir tanesi gri renkli erken bir örnek olup diğeri kırmızı astarlı ve bezemesizdir. Ortaçağ seramikleri de yivli bir örnek dışında bezemesizdir ve hepsi ince cidarlı olup mika, beyaz taşçık, kireç ve organik hamur katkılıdırlar. Sulakyurt buluntu alanında olduğu gibi Doğankaya' da da hiç mimari kalıntıya rastlanılmamış olması, alanın ne amaçla kullanıldığının anlaşılmasını mümkün kılmamıştır.

\section{Şeytan Kalesi}

Şeytan Kalesi; Çıldır'ın kuzeydoğusunda yer alan ve eski adı Gürcüce Rabat (Rabati / nsososool) olan Yıldırımtepe Köyü'nün 1,5-2 km kadar kuzeyindedir (Harita 1; Resim 11). Rabat sözcügü Gürcüceye Arapça "ribat (الرباط)" sözcüğünden kazandırılmıştır. Kale; Karaçay Vadisi'nde, Karaçay'ın kuzey, güney ve doğu yönlerinden çevrelediği oldukça sarp ve kayalık bir yarımada üzerinde konumlandırılmıştır (Sinclair 1987: 429-430). Burçlar, duvar örgüsü ve diğer mimari birimler kalenin tipik bir Ortaçağ yapısı olduğunu gösterir. Kale içerisinde bir Ortaçağ Gürcü şapeli, bu şapelin $23 \mathrm{~m}$ kadar kuzeydoğusunda yer alan yuvarlak planlı bir su sarnıcı ve ayrıca kalenin güneybatı sur duvarına bitişik inşa edilmiş ve muhtemelen depo işlevinde kullanılmış dikdörtgen planlı bir yapı bulunmaktadır. Bu yapılar dışında, su sarnıcının kuzey ve kuzeybatısında kalan alanda, temel seviyesinde gözlemlenebilen farklı yapılara ait kalıntılar vardır. Buradaki mimari kalıntıların işlevini anlayabilmek için arkeolojik bir kazı yapılmas1 gerekir.

Şeytan Kalesi içerisinde arazi üzerinde gözlemlediğimiz çanak çömlekler genel olarak Ortaçağ'a tarihlenmektedir. 2017 yılı yüzey araştırması sırasında kalede iki kaçak kazı çukuru tespit edilmiştir. Bu kaçak kazı çukurlarından ilki, kale içerisinde, ana burcun $37 \mathrm{~m}$ kadar kuzeydoğusunda, yuvarlak planlı su sarnıcının ise $43 \mathrm{~m}$ kadar batısında tespit edilmiştir. Bu kaçak kazı çukurunun atım toprağı üzerinde gözlemlediğimiz çanak çömleklerden bazılarının İ.Ö. 5. yüzyıla (Resim 12), bir tanesinin ise İ.Ö. 4. yüzyıla, belki de bu yüzyılın sonlarına ait olduğu düşüncesindeyiz (Resim 13). Bu seramik parçası daha çok Batı Anadolu'da görmeye aşina olduğumuz ince cidarlı, siyah parlak firnisli ve birbirine paralel yatay yivlerle gövdesi bezeli Hellenistik Dönem seramiklerini anımsatmaktadır. Ardahan'da ve yakın çevresinde bu tipte seramiklere rastlanılmamaktadır. Diğer kaçak kazı çukuru, kalenin doğu surunun hemen iç kısmında, su sarnıcının 32-33 m kadar doğusundadır. Buradaki buluntular Ortaçağ seramiklerinden oluşmaktadır. Önceki yıllarda yapılmış bir araştırmada, yine kale içerisinde Tunç Çağ 1 çanak çömlekleri tespit edildiği bilinmektedir (Topaloğlu 2006: 123-124). Çanak çömlek parçaları, Ortaçağ dönemine ait kale yapısından önce de burada yerleşim olduğuna işaret etmektedir. Ancak böyle bir durumda dahi Şeytan Kalesi'nin inşasından önce aynı noktada bir savunma yapısının varlığını, şu an için, birkaç parça çanak çömlekten yola çıkılarak kesin bir dille ileri sürülemez. Bu konudaki asıl bakılması gereken arkeolojik veri, mimari buluntulardır. Kalenin önceki dönemlerine ilişkin tespitler ancak bölgede yapılacak arkeolojik bir kazı ile belirlenebilecektir. 


\section{Bellitepe Kilisesi}

2017 yılı araştırmaları sırasında, Ölçek Köyü'nün 1,7 km kuzeydoğusunda, Balıkçılar köyünün merkezinde, Sulakyurt köyünün $5,5 \mathrm{~km}$ güneydoğusunda, Bellitepe'de ve Eskibeyrehatun Köyü içerisinde Ortaçağ şapelleri ve bir kilise incelenmiştir (Harita 1). Şapeller; Ardahan ve çevresinde sıkça karşılaşılan tek nefli ve dolgu duvar tekniğinde inşa edilen dini yapılardandır. Kilise ise Bellitepe Köyü sınırlarında yer almaktadır. Bellitepe'nin $4 \mathrm{~km}$ doğusundaki kilise, modern yolun $150 \mathrm{~m}$ kuzeyinde ve Kura Nehri'nin 215 m kuzeyinde, $2010 \mathrm{~m}$ yüksekliğindeki bir tepenin yamacında yer almaktadır (Harita 2).

Bellitepe Kilisesi, 10 × 6.80 m ölçülerinde ve dolgu duvar tekniğinde inşa edilmiştir (Resim 14). Tek nefli yapının kuzey kenarına bitişik inşa edilmiş ek bir mekân daha bulunmaktadır. Bu mekân 5,40 x 2,50 m boyutlarında olup muhtemelen bir pastophorion işlevinde kullanılmış olmalıdır. Kilisenin kapladığı alanın toplam boyutu, bu ek mekânla birlikte 10 x 9.15 m'ye yükselmektedir. Kilisenin duvar kalınlığ 1 yaklaşık $80 \mathrm{~cm}$, duvarlarının korunan maksimum yüksekliği ise 4,60 m'dir. Kilisenin girişi batı kenardadır ancak yapının bu kısmı büyük oranda tahrip olmuştur. Duvar yüzeylerindeki düzgün kesme taşların zaman içerisinde bölge sakinlerince alındığı anlaşılmaktadır. Kilisenin $10 \mathrm{~m}$ kadar güneyinde, bir kaçak kazı sonucu ortaya çıkmış bir Ortaçağ mezarı 2017 yılı araştırmaları sırasında ayrıca tespit edilmiştir.

\section{Dedeşen (Gümüşparmak) Ortaçağ Yerleşimi}

Ardahan'ın Ortaçağ arkeolojisi üzerine yapılan kapsamlı araştırmalar 1990'lı ve 2000'li yıllarda hayata geçirilmiştir. Prof. Dr. Fahriye Bayram'ın başkanlığında tamamlanan Ardahan İli Ortaçağ Gürcü dini mimarisi yüzey araştırmaları sırasında genel olarak İ.S. 10.-12. yüzyıllara tarihlenen çok sayıda yap1 kalıntısı tespit edilmiştir (Bayram-Yazar 2008: 266-277; Bayram-Yazar 2011: 2-8; Bayram-Yazar 2013: 328-329). Esasında Ortaçağ arkeolojisi üzerine Ardahan'daki ilk araştırmalar Gürcü tarihçi ve arkeolog E. Takaishvili tarafından 20. yüzyılın başında gerçekleştirilmiştir (Takaishvili 1903: 309; Takaishvili 1909: 84-117; Takaishvili 1924; Takaishvili 1938). 1977 ve 1983 y1llarında $R$. $W$. Edwards, Erzurum, Artvin ve Ardahan çevresi Ortaçağ kalıntıları konusunda önemli incelemelerde bulunmuştur (Edwards 1986, 165-182; Edwards 1988, 119141). Bu araştırmalar sırasında Edwards'ın cevap aradığı konulardan biri, Artvin ve Ardahan bölgesinde Ermeni ve Gürcü kültürlerinden hangisinin baskın olduğuydu. Edwards, Ortaçağ Gürcü kültürüne ilişkin çok sayıda veri ile karşılaşmışsa da bu konuda kesin bir yorum yapmaktan kaçınmıştır. Ardahan'da araştırmalarda bulunan bir diğer Avrupalı araştırmacı, kısa periyotlar halinde 1980'li yıllarda ve ayrıca 1990 yılında bölgeyi ziyaret eden Avusturyalı B. Baumgartner'dir (Baumgartner 2009, 183-187). Baumgartner, il sınırları içerisindeki Ortaçağ Gürcü kültürüne ait izleri takip etmiş ve bazı mimari yapılar üzerinde çalışmıştır.

Dedeşen (günümüzdeki adıyla Gümüşparmak) Arkeolojik Alanı, Ardahan'da Ortaçağ'a tarihlenen en önemli arkeolojik alanlardan biridir. Bu köy, Kuzupınarı ve Bellitepe arasındaki ovanın güney merkezinde yer almaktadır ve 
Kuzupınarı'nın 4.5 km doğusundadır (Harita 1-2). Ortaçağ dönemine ait yerleşim kalıntıları, köyün hemen kuzey kenarındaki bir höyügün üzerinde yer almaktadır (Resim 15). Tarihi Tao-Klarceti Bölgesi'nin parçası olan Artvin ve Ardahan'da, 10. ve 13. yüzyıllar arasına tarihlenen çok sayıda kalıntı olduğu bilinse de Ardahan'da bu kalıntıların çoğu kötü derecede korunmuştur. Bu önemli buluntulardan biri, İ.S. 5. yüzyılda, Kral Vakhtang I döneminde bir piskoposluğun kurulmuş olduğunu bildiğimiz Ardahan Ovası'nın kuzeyindeki Erusheti'de bazilikal planlı bir dini yapı idi. Dedeşen'de yer alan bu Ortaçağ yerleşimi de düşüncemize göre Ardahan'da savunma duvarlarıyla güçlendirilmiş önemli dini merkezlerden biri olmaliyd.

2020-2050 m rakımları arasında yer alan Dedeşen Höyüğü doğu-bat1 doğrultusunda $420 \mathrm{~m}$ ve kuzey-güney yönünde ise $230 \mathrm{~m}$ 'lik bir alanı kaplamaktadır. Höyük üzerindeki mimari kalıntılar, doğu-batı yönünde $330 \mathrm{~m}$ boyunca gözlemlenebilmektedir. Höyüğün güneybatı kenarında yer alan savunma duvarı birkaç metre uzunlukta korunabilmiştir (Resim 16). Duvarın korunduğu bu nokta arkeolojik alanın girişi olmalıdır. Ne yazık ki tüm höyüğü çevrelediğini düşündüğümüz bu güçlü surun neredeyse tamamı tahrip olmuştur. Ancak burada bir arkeolojik kazı yapıldığı taktirde, toprak altından duvarların en azından temellerinin ortaya çıkarılabileceği düşüncesindeyiz.

14.4 x 9.9 m boyutlarındaki bir Ortaçağ Kilisesi höyüğün doğu kenarında yer almaktadır (Resim 17). 10 m'yi aşan uzunluğuyla Ardahan'daki ender kiliselerden biri olan bu dini yapı büyük ölçüde tahrip olmuştur. Dolgu duvar tekniğinde inşa edilen yapının kuzey duvarı 3.30 m yükseklikte korunabilmiştir. Kilisenin diğer duvarları genel olarak arazi seviyesinde korunabilmiş olup duvar kalınlıkları $70 \mathrm{~cm}$ civarındadır. Yapının kuzeydoğu kenarına bitişik inşa edilmiş ek bir mekân daha bulunmaktadır. Bu mekânın güney kenarda bir simetrisi daha olması gerekmektedir ancak yapının bu kenarında yıkılan duvarlar güney ek mekânın ayrıntılı bir şekilde incelenmesini engellemiştir.

Kilisenin hemen batısındaki alan bir mezarlık olarak kullanılmıştır ve çok sayıda mezar taşı, doğu-batı doğrultusunda arazi üzerinde gözlemlenebilmektedir (Resim 18). Mezar taşlarının haricinde, mezarlığın batı kenarında bazı mimari kalıntılar oldukça kötü durumda, temel seviyesinde korunmuştur ancak bu kalıntıların işlevini anlayabilmek mümkün değildir. Dedeşen Höyüğü üzerinde yapmış olduğumuz incelemelerde Ortaçağ'a ait az sayıda çanak çömlek buluntusu tespit edilebilmiştir.

\section{Sonuç}

Ardahan İli 2017 y1lı arkeolojik yüzey araştırmasında, ilin eskiçağ savunma yapılarının ve mevsimlik yerleşimlerinin daha iyi anlaşılabilmesi adına önemli veriler elde edilmiştir. Merkez ilçedeki arkeolojik merkezlerden Ölçek Kuzey Kalesi, Kura Nehri yakınına kurulmuş orta boyutlu bir savunma noktasıdır. Gölgeli Güneybatı Kalesi sağlam savunma duvarlarına sahip, kayalık bir zemin üzerine kurulmuş, mevsimlik bir yayla yerleşiminin ve bu yerleşime bağlı hayvancılık faaliyetlerinin korunması maksadıyla oluşturulmuş büyük boyutlu bir 
yapıdır. Beşiktaş Kalesi ise Ardahan'da tespit edilen en büyük boyutlu arkeolojik alanlardandır. İki sur sırasına sahip korunaklı arkeolojik alan esasında dış duvar sıralarıyla güçlendirilmiş bir tepe yerleşimidir. Gölgeli Güneybatı Kalesi ve Yerleşimi'nde hem II. binyıl hem Demir Çağı çanak çömlekleri tespit edilmiş, Beşiktaş'ta da aynı dönem çanak-çömlekleri takip edilebilmektedir; ancak buluntular Gölgeli'ye göre sayıca daha azdır. Beşiktaş'ın Ardahan'daki diğer arkeolojik buluntu noktalarından ayıran en önemli özelliği, II. binyıl Kurgan tipi mezarlarıdır. Bu konu başlığında, Ardahan'da Beşiktaş dışında bilinen buluntu noktaları Akçakale Adası ve Kurtkale'dir. Aynı zamanda Geç Tunç ve Erken Demir Çağı seramiklerinin tespit edildiği Kartalpınar Kalesi ve Mezarlık Alanı'nda da kurgan tipi mezarlar 2014 yılında araştırma ekibimizce tespit edilmiştir. Fakat bu buluntular için kesin bir tarih ileri sürmek için henüz erken olup Doğu Anadolu arkeolojisi adına oldukça önemli bu alanda mutlaka bir kazı yapılması gerekmektedir. Çok sayıdaki mekân kalıntısı ve savunma duvarlarıyla Beşiktaş'ın Çıldır İlçesi'ndeki Senger Tepe arkeolojik alanı ile aynı perspektifte değerlendirilmesi gereken bir buluntu noktası olduğunu düşünmekteyiz.

Göle ilçesindeki buluntu noktalarında Demir Çağı'nın kendisini daha yoğun bir şekilde hissettirdiğini söyleyebiliriz. Özellikle Kuzupınarı ve Bellitepe yerleşimleri arasındaki buluntu noktaları Demir Çağı Ardahan'ı adına önemli veriler sağlamaktadır. Kuzupınarı Kalesi, Bellitepe Batı ve Doğu Kuleleri ve muhtemel bir eskiçağ ağıll, Göle'nin bu bölgesinin özellikle Demir Çağı arkeolojisi açısından daha detaylı araştırılması gerektiğini göstermektedir. Göle'deki diğer önemli buluntu yeri olan Çobanköy'de aynı zamanda bir yerleşim olarak kullanılmış olması gereken bir kale ve bir höyük tespit edilmiştir ki bu iki arkeolojik noktada da Demir Çağı çanak çömlekleri daha erken örneklerin yanı sıra gözlemlenebilmiştir. Çobanköy Höyüğü Ardahan'da tespit edilen ender höyüklerden biri olması açısından önemli olsa da bu buluntu alanının insan eliyle oldukça tahrip edildiği tespit edilmiştir.

Ardahan'ın merkez ilçesi yerleşimlerinden Sulakyurt'un doğusunda ve Çıldır'a bağlı Doğankaya'da Demir Çağı ve Ortaçağ'a tarihlenen çanak çömlek buluntuları tespit edilmiş; yine Çıldır'ın en önemli arkeolojik kalıntılarından olan Şeytan Kalesi'nde ise İ.Ö. 5. ve 4. yüzyıllara ait olması gereken çanak çömlek buluntuları Ortaçağ çanak çömleklerinin haricinde gözlemlenmiştir. İ.Ö. 4. yüzyılın sonlarına ait olabileceğini düşündügümüz ince cidarlı, siyah firnisli ve yiv bezemeli bir açık kap parçası ise (Resim 13) Doğu Anadolu'dan ziyade Batı Anadolu'da görülebilecek kapları bizlere anımsatmaktadır. Böylesi bir buluntu, Ardahan ve Kuzeydoğu Anadolu arkeolojisi adına oldukça ilginç olmalıdır. Görünen o ki, Şeytan Kalesi’nde arkeolojik bir kazı yapılması halinde, Ortaçağ adına doyurucu verileri elde edebilmenin dışında, belki de şaşırtıcı arkeolojik buluntular da ortaya çıkarılabilecektir.

Yapılan araştırmalar sırasında Ölçek, Balıkçılar, Sulakyurt, Eskibeyrehatun, Bellitepe ve Dedeşen'de Ortaçağ dini mimarisi adına önemli yapılarla da karşılaşılmıştır. Bellitepe ve Dedeşen'deki iki kilise dışındakiler tek nefli şapellerdir ve ne yazık ki bu yapıların tahribata uğradığı görülmüştür. Ortaçağ 


\section{Ardahan İli 2017 Yılı Arkeolojik Yüzey Araştırması}

arkeolojik buluntu noktalarından bir höyük üzerinde yer alan Dedeşen arkeolojik alanı, kilisesi, sur kalıntıları, mezarlığı ve arazi seviyesinde tespit edilebilen diğer kalıntılarıyla birlikte Ardahan sınırları içerisindeki en önemli Ortaçağ buluntu alanlarından biri olmalıdır. Kuzupınarı, Bellitepe ve Dedeşen, aynı ovanın çevresinde tespit edilen arkeolojik alanlardır ve bu ovanın çevresi hem Demir Çağı'nda hem de Ortaçağ'da yerleşim görmüştür. Aktarılan bu buluntu grubunun haricinde, Ardahan'daki yüzey araştırmalarımızın son sezonu olan 2018 yılında, Bellitepe' nin kuzeyinde kare planlı bir kale kalıntısı daha tespit edilmiştir (Harita 2). ${ }^{2}$

\section{Kaynakça}

Baumgartner, B. (2009). "Unknown and Less Known Georgian Monuments in Northeast Turkey", şurada: P. Skinner, D. Tumanishvili ve A. Shanshiashvli (yya.), The Proceedings of the 1st International Symposium of Georgian Culture: Georgian Art in the Context of European and Asian Cultures, June 21-29, 2008, Georgia. Georgian Arts \& Culture Center, Tbilisi, 183-187.

Bayram, F. ve Yazar, T. (2008). "Artvin, Erzurum, Ardahan İli ve İlçelerinde Gürcü Mimarisi Yüzey Araştırmas1- 2006", 25. Araştırma Sonuçları Toplantısl, I. Cilt, (28 Mayıs-01 Haziran 2007 Çanakkale), Ankara, 263284.

Bayram, F. ve Yazar, T. (2011). “Artvin, Erzurum, Ardahan İli ve İlçelerinde Ortaçağ Gürcü Mimarisi Yüzey Araştırmas1-2009”, 28. Araştırma Sonuçları Toplantısı, I. Cilt, (24-28 Mayıs 2010 İstanbul), Ankara, 1-18.

Bayram, F. ve Yazar, T. (2013). "Artvin, Erzurum, Ardahan İli ve İlçelerinde Ortaçağ Gürcü Mimarisi Yüzey Araştırmasi-2011”, 30. Araştırma Sonuçları Toplantısı, 2.Cilt, (28 Mayıs-1 Haziran 2012 Çorum), Çorum, 321-336.

Çilingiroğlu, A. (1997). Urartu Krallı̆̆l, Tarihi ve Sanatı, Yaşar Eğitim ve Kültür Vakfi.

Edwards, R.W. (1986). "The Fortifications of Artvin: A Second Preliminary Report on the Marchlands of Northeast Turkey", Dumbarton Oaks Papers 40, 165-182.

Edwards, R.W. (1988). "The Vale of Kola: A Final Preliminary Report on the Marchlands of Northeast Turkey", Dumbarton Oaks Papers 42, 119-141.

Forbes, T. B. (1983). Urartian Architecture, BAR IS 170, Oxford.

Köroğlu, K. (1998). "1996 Yılı Artvin-Ardahan İlleri Yüzey Araştırması”, XV. Araştırma Sonuçları Toplantıs1, I. Cilt, Ankara, 127-156.

Köroğlu, K. (2000). "Çıldır Kurganları / The Kurgans of Çıldır", Arkeoloji ve Sanat 96, 2-11.

${ }^{2} \mathrm{Bu}$ araştırmanın sonuçlarını içeren detaylı bir değerlendirmenin yakın zaman içinde yayımlanması da planlanmaktadır. 
Özfirat, A. (2001). Doğu Anadolu Yayla Kültürleri (M.Ö. II. Binyıl), Arkeoloji ve Sanat Yayınları, İstanbul.

Özfırat, A. (2002). "Doğu Anadolu Yüksek Yaylası'ndan M.Ö. 2. Binyıl Kurganlar1", Belleten LXVI-246, 343-371.

Özfirat, A. (2009a). "Bozkurt Kurgan Mezarlı̆̆1 Kazıları", Belleten LXXIII-268, 635-674.

Özfirat, A. (2009b). "Excavation of Bozkurt (on the skirt of Mt. Ağrı) Kurgan Cemetery, 2007: First Preliminary Report", Archäologische Mitteilungen aus Iran und Turan 41, 233-247.

Özfirat, A. (2010). "Bozkurt Kurgan Mezarlığı", Aktüel Arkeoloji 15, 42-43.

Özfirat, A. (2014). "Bozkurt Kurgan Mezarlı̆̆1 Kazıs1, 2007-2013", 36. Kazı Sonuçları Toplantısı, 2. Cilt, (Gaziantep, 02-06 Haziran 2014), Ankara, 209-226.

Patacı, S. (2019). “Ardahan'daki Gölgeli ve Çobanköy Demir Çağı alanları", Karadeniz 41, 106-119.

Patac1, S. ve Oral Patacı, Ö. (2018). "Some Iron Age and Medieval Sites in Göle District of Ardahan". History, Archaeology, Ethnology, [S.I.] No I, 1630.

Patac1, S. ve Laflı, E. (2019). "Ardahan'da Arkeolojik Araştırmalar: 2015 Y1lı Yüzey Araştırması", Rifat Ergeç Armağanı, Bilgin Kültür Sanat Yayınlar1, 261-276.

Patac1, S. ve Lafl1, E. (2017). "Field Surveys in Ardahan in 2016", Anatolia Antiqua 25, 115-126.

Patac1, S. ve Lafli, E. (2016). "Field Surveys in Ardahan in 2015", Anatolia Antiqua 24, 281-297.

Patac1, S. ve Lafl1, E. (2015). "Surveys in Ardahan on the Turkish-Georgian Borderline in 2013 and 2014", Anatolia Antiqua 23, 229-248.

Patac1, S., Yıldırım, N., Oral Patacı, Ö., Bozoğlu, İ., Altun, S. (2017). "Ardahan İli 2013-2015 Yılları Yüzey Araştırmaları", 34. Araştırma Sonuçları Toplantısl, 1. Cilt, (Edirne), 175-200.

Sinclair, T. A. (1987). Eastern Turkey: An Architectural And Archaeological Survey, Vol. I, Pindar Press, London.

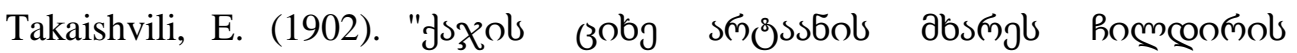

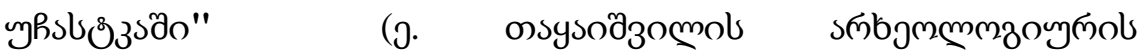

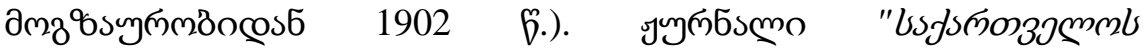

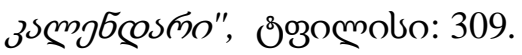

Takaishvili, Е. (1909). "Христианские памятники, (Экскурсия 1902 года)”, Материалы по археол. Кавказа, собран. экспед. Имп. Моск. археол. o-ва. Bbin. 12, 84-117. 


\section{Ardahan İli 2017 Yılı Arkeolojik Yüzey Araştırması}

Takaishvili, E. (1924). Kharthuli hurothmodzgwrebis albomi, Nahazebi šerrnlebulis hurothmodżंwartha da mhatwartha Ebralidzisa / Album d'architecture géorgienne, Universitetis gamocema (Tbilisi).

Takaishvili, E. (1938). Expédition archéologique en Kola-Olthissi et en Tchangli, Paris.

<http://dspace.nplg.gov.ge/bitstream/1234/10599/1/TaKaishvili_Eqvtime. pdf $>(08 / 05 / 2016)$.

Topaloğlu, Y. (2006). Ardahan Çıldır Bölgesi Tarihi ve Arkeolojik Araştırmaları, (Yayımlanmamış Yüksek Lisans Tezi), Atatürk Üniversitesi, Sosyal Bilimler Enstitüsü, Tarih Anabilim Dalı, Erzurum.

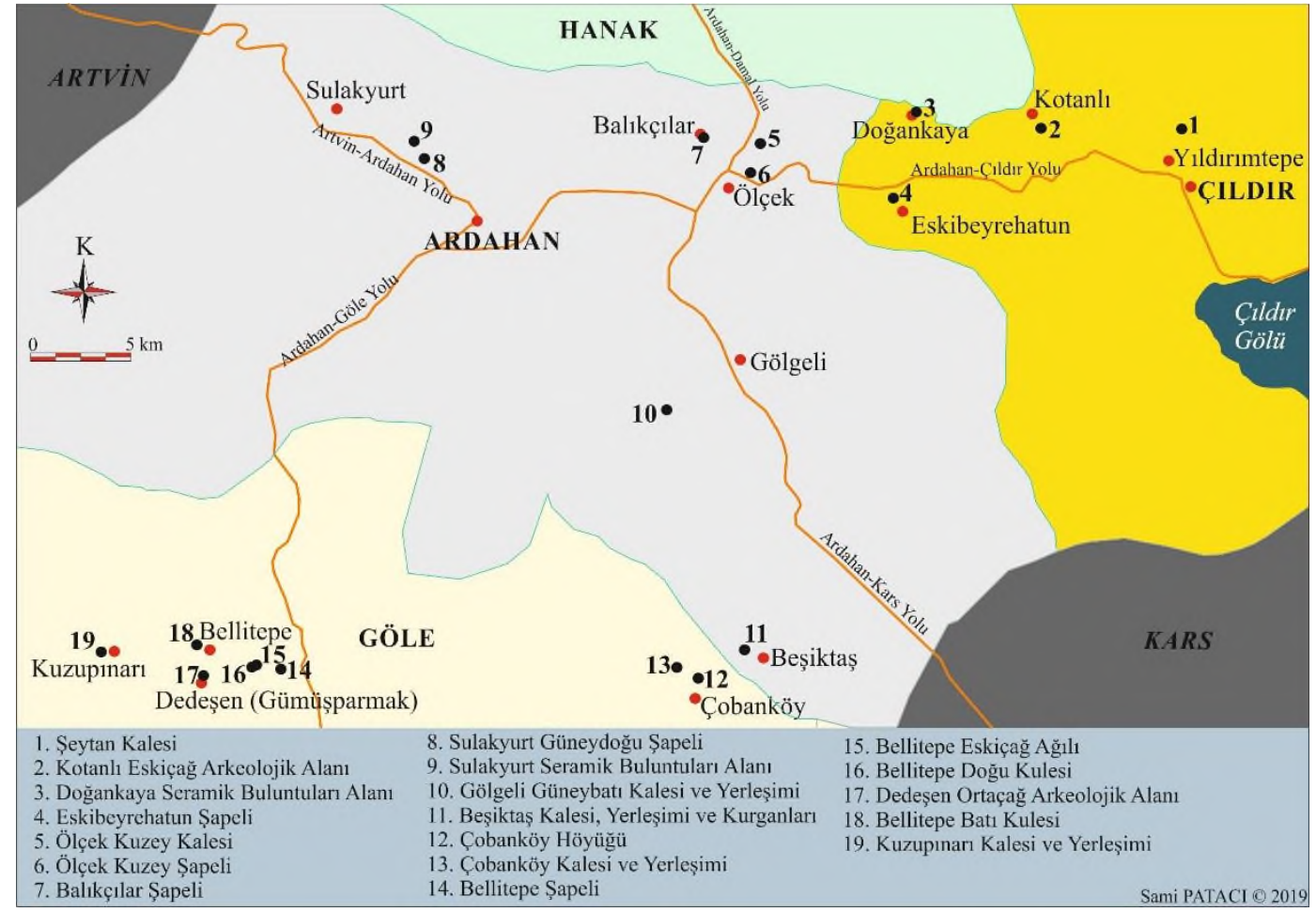

Harita 1. 2017 yılı yüzey araştırması haritas1. 


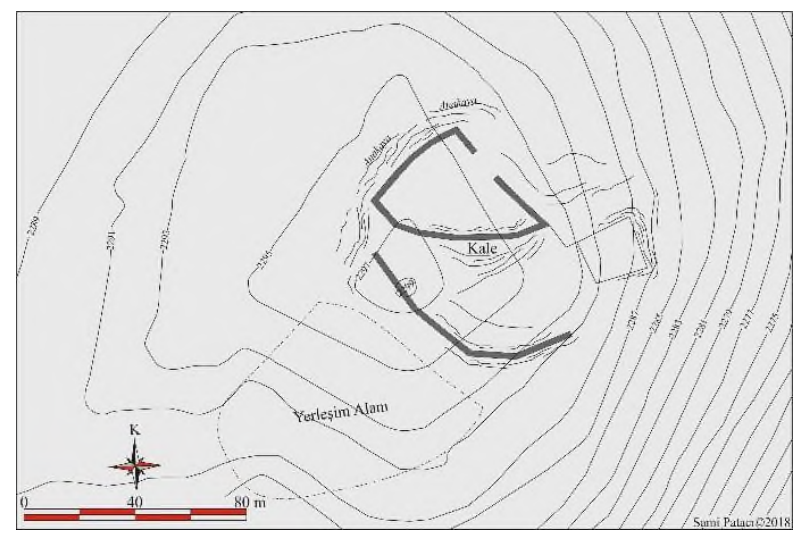

Çizim 1. Gölgeli Güneybatı Kalesi topografik planı.

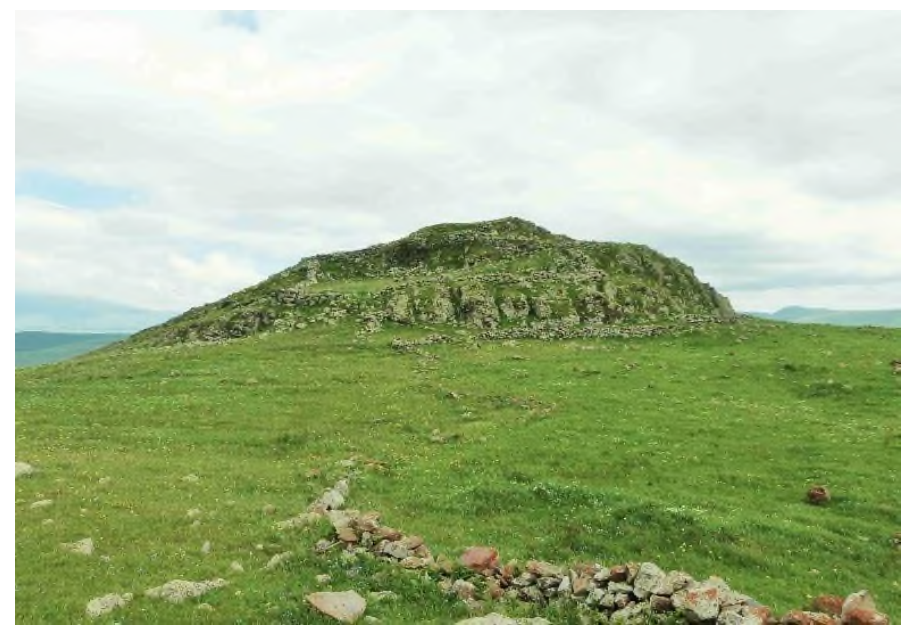

Resim 1. Gölgeli Güneybatı Kalesi'nin kuzeyden görünümü. 


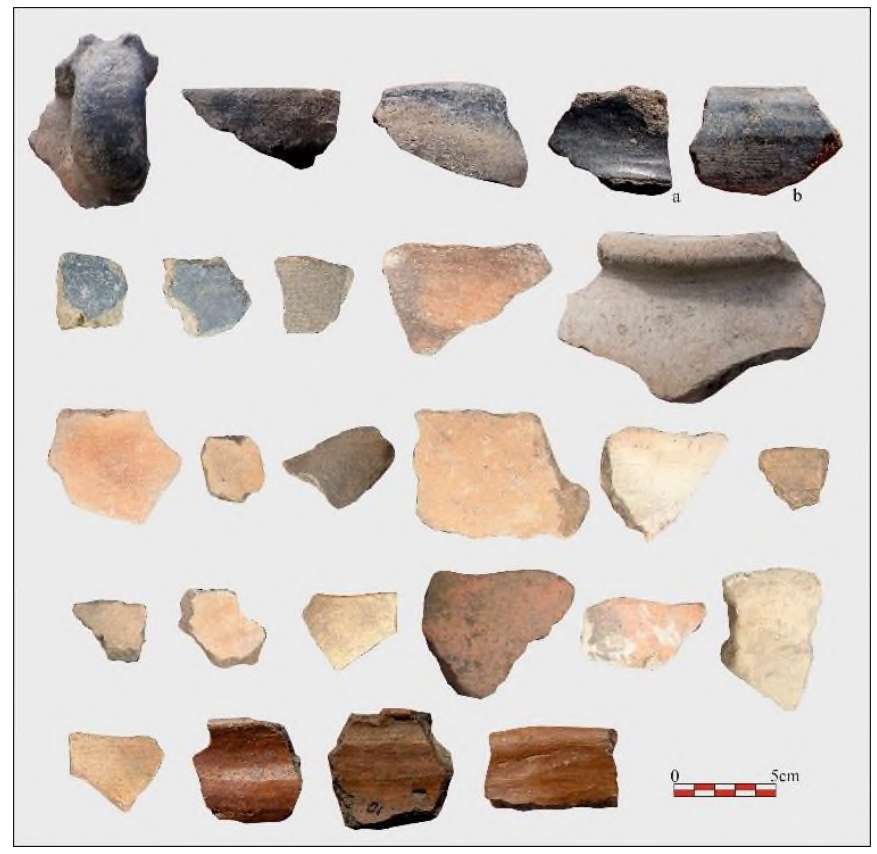

Resim 2. Gölgeli Güneybatı Kalesi ve Yerleşimi çanak-çömlek buluntuları. 


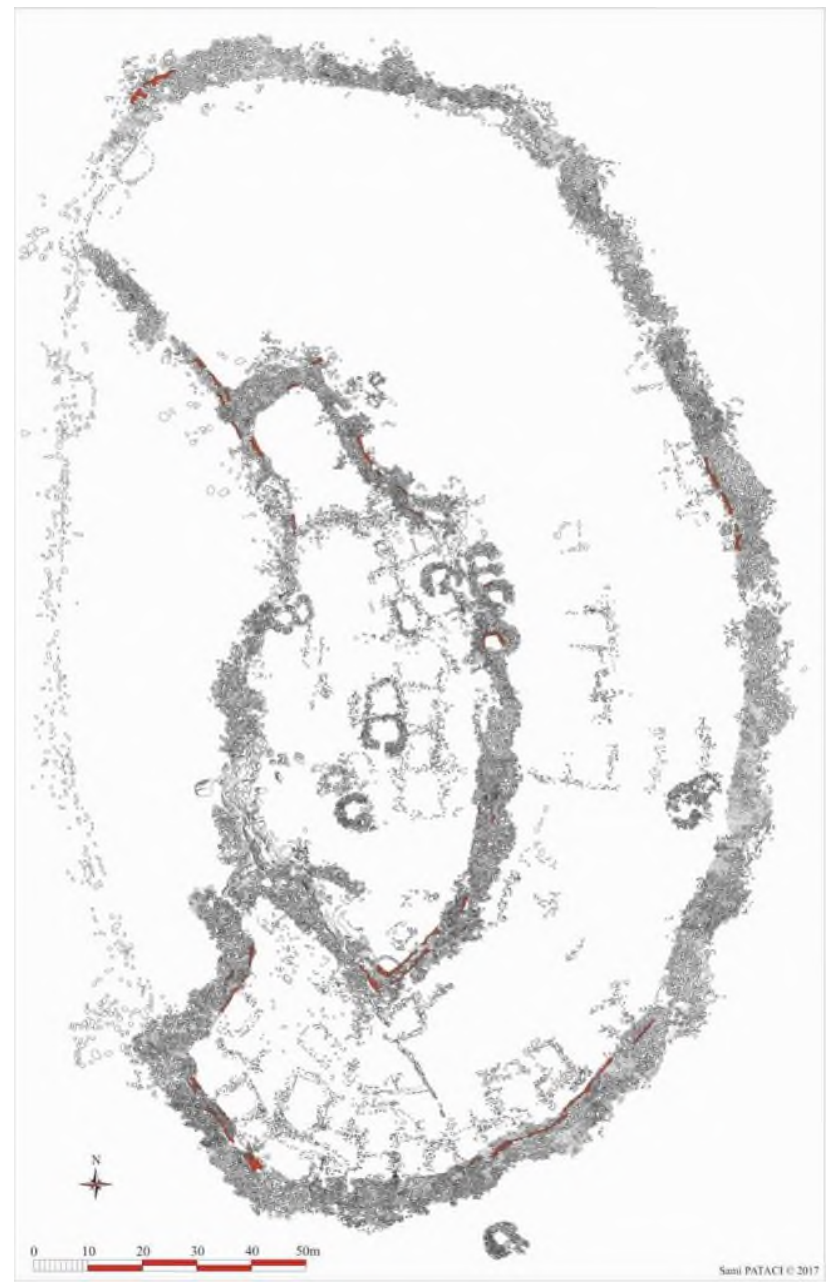

Çizim 2. Beşiktaş Kalesi ve yerleşimi planı. 


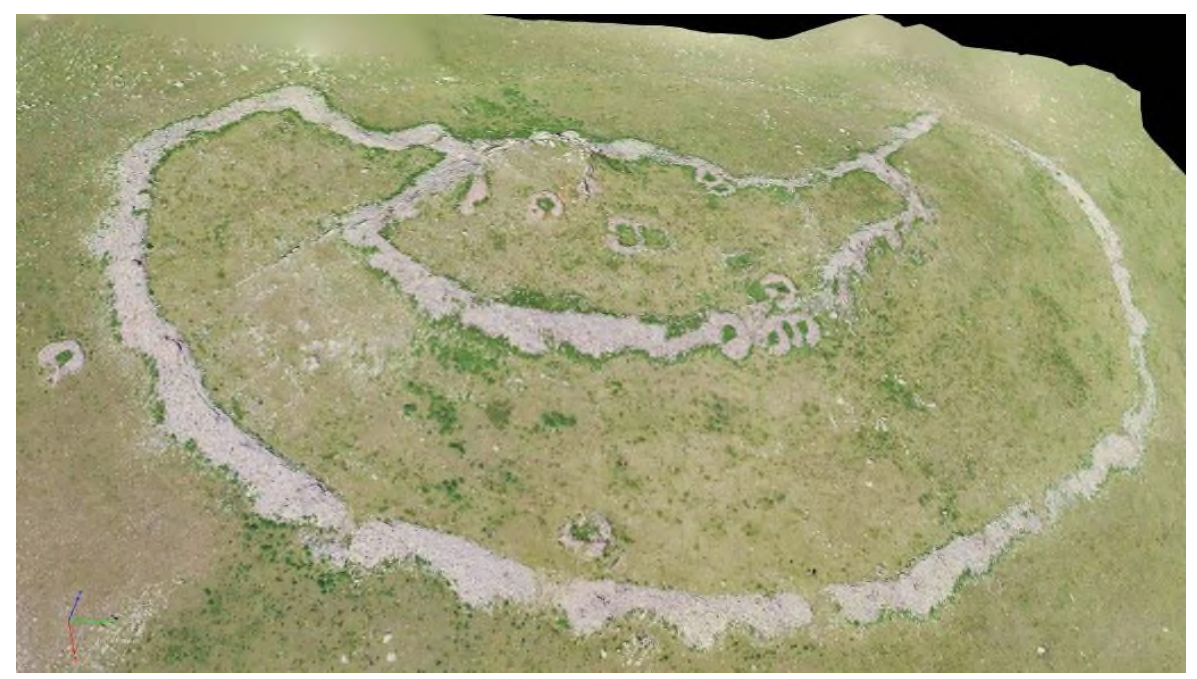

Resim 3. Beşiktaş Kalesi ve Yerleşimi 3D modellemesi.

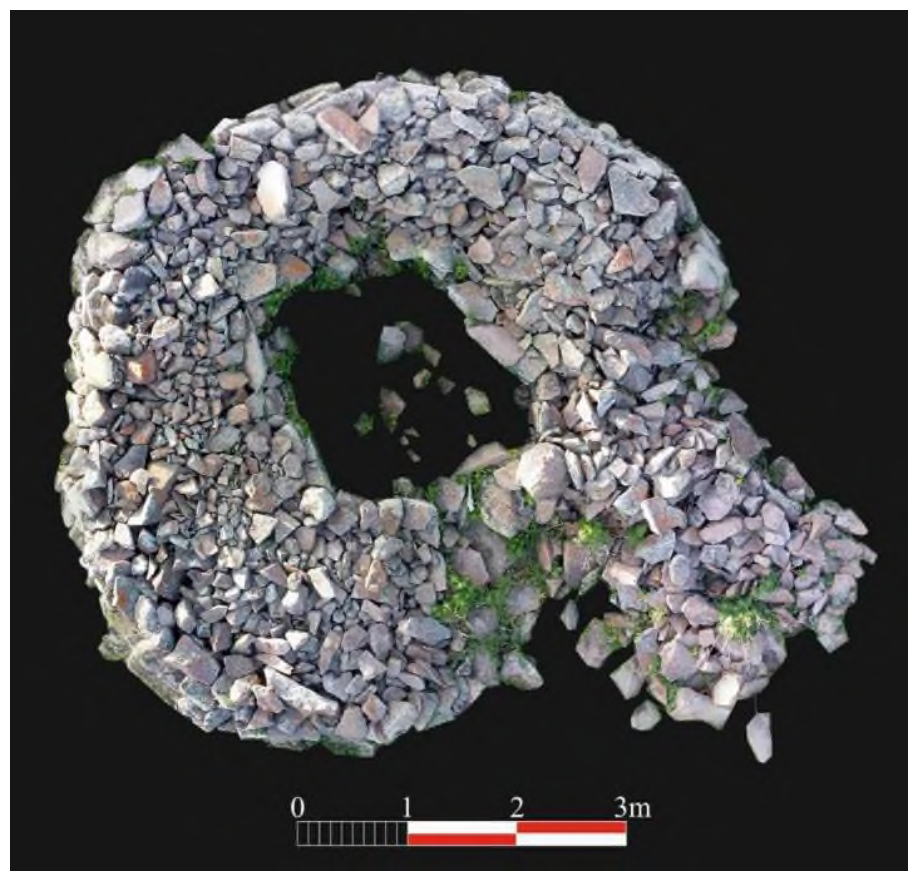

Resim 4. Beşiktaş Kurganı'nın ortofotosu. 


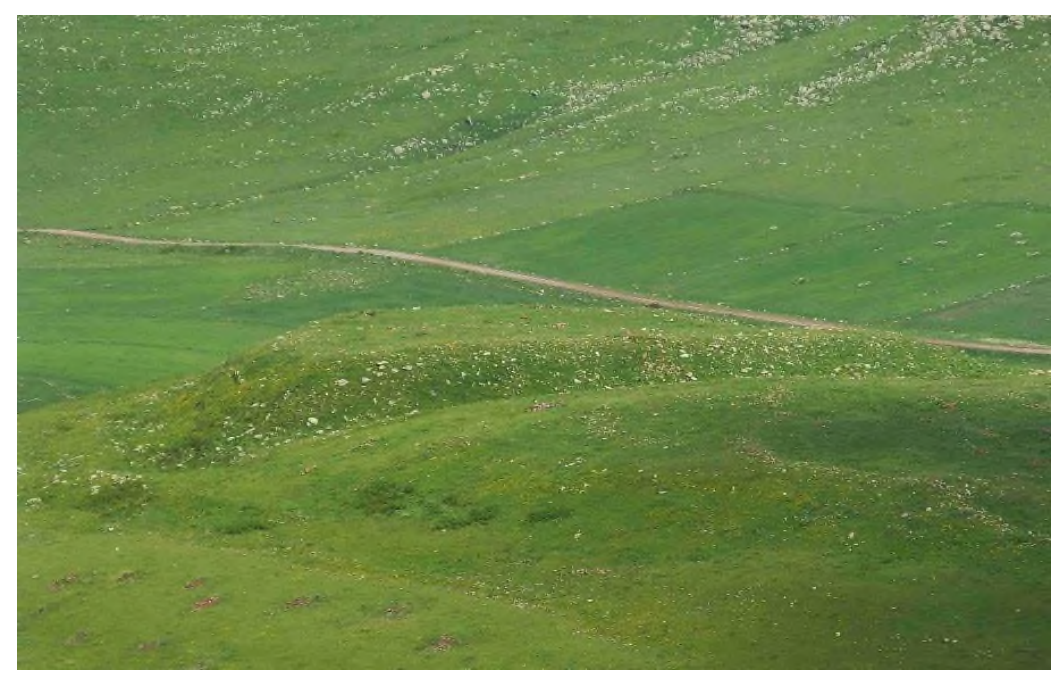

Resim 5. Çobanköy Höyügü̈'nün kuzeybatıdan görünümü.

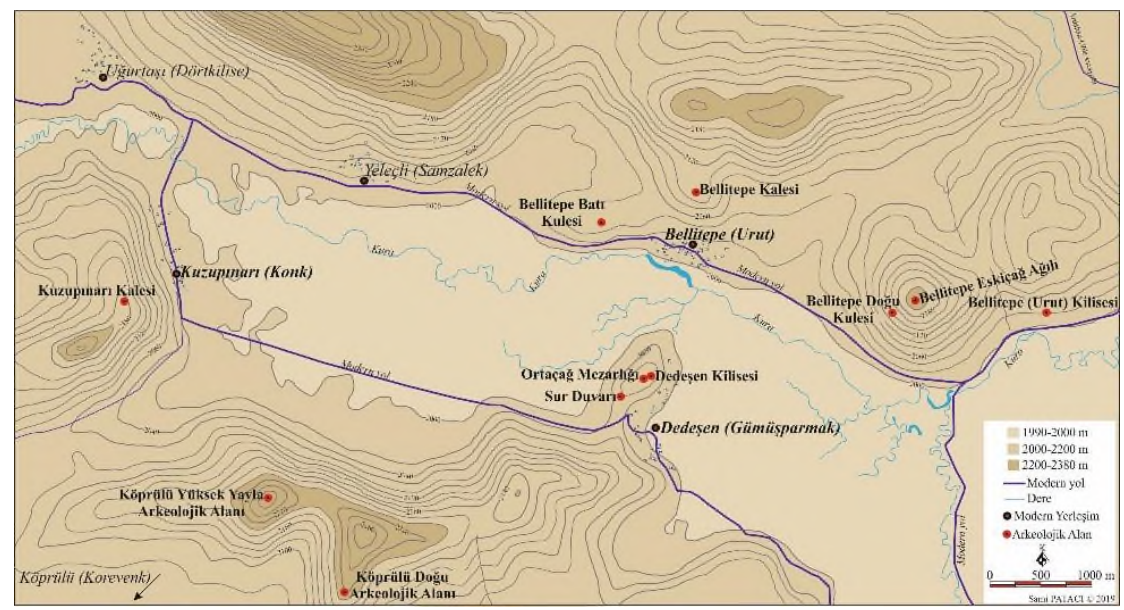

Harita 2. Kuzupınarı ve Bellitepe arasındaki arkeolojik alanlar. 


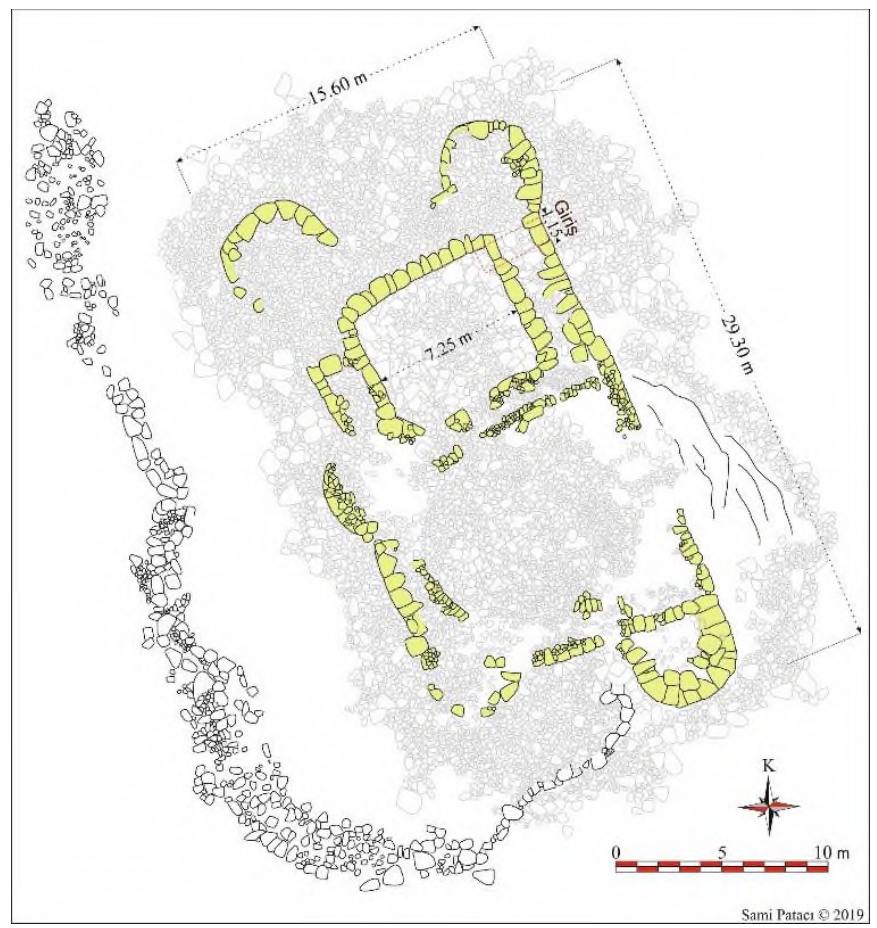

Çizim 3. Kuzupınarı Kalesi planı.

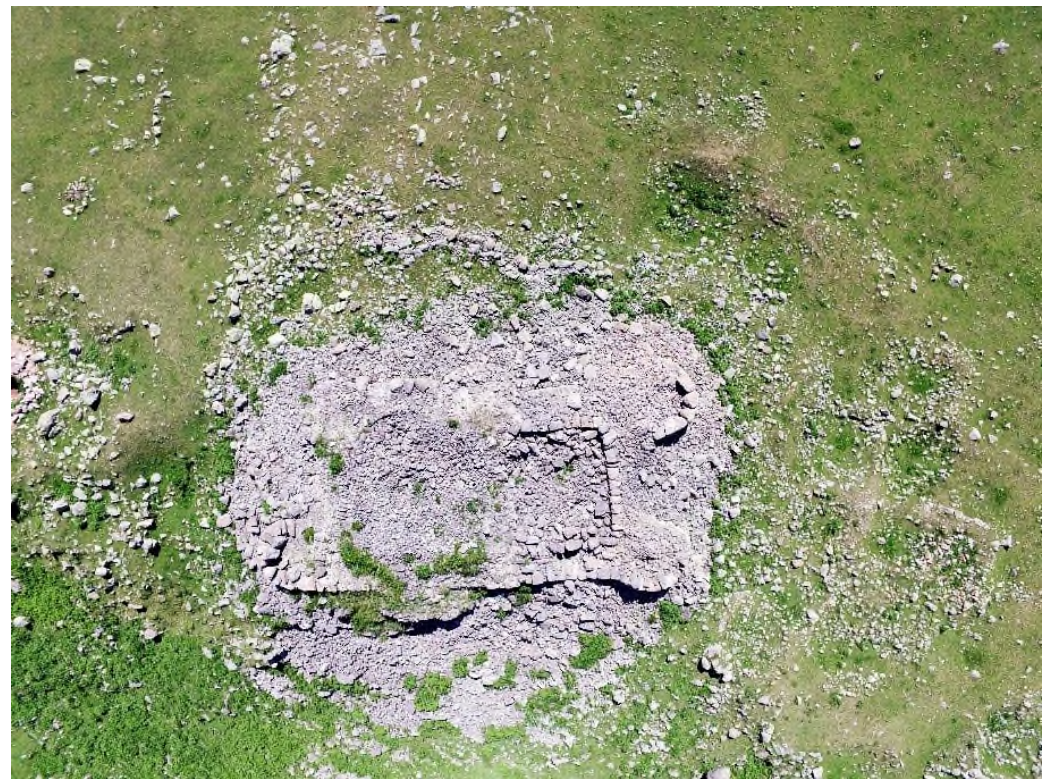

Resim 6. Kuzupınarı Kalesi hava fotoğrafi. 
Sami PATACI - Özlem ORAL PATACI

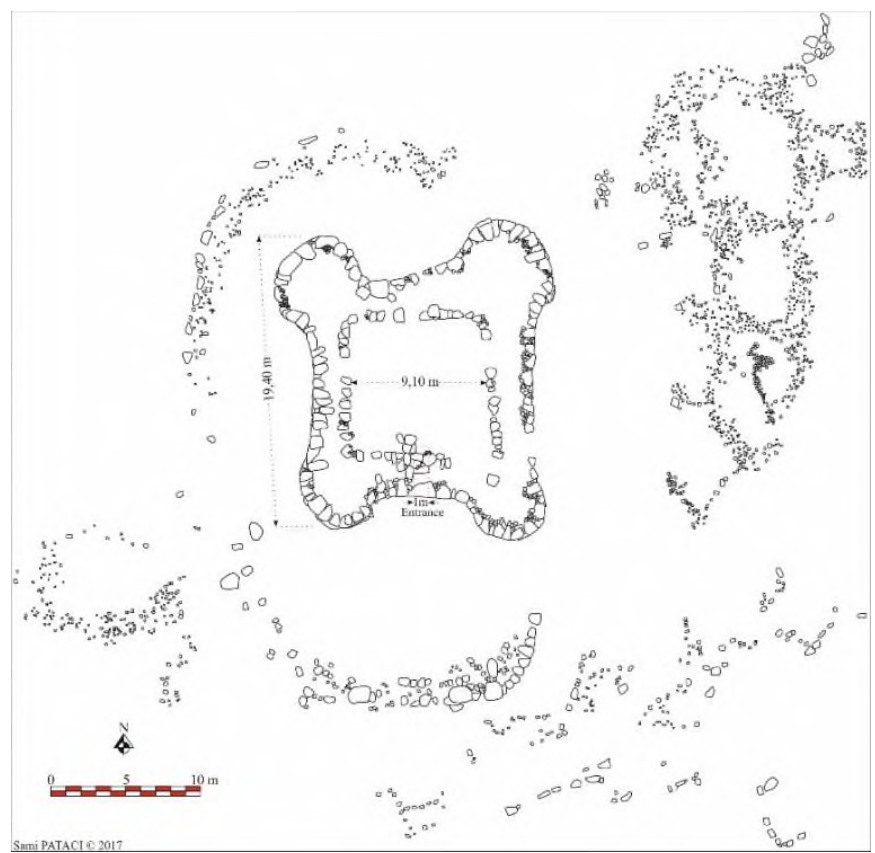

Çizim 4. Bellitepe Batı Kulesi planı.

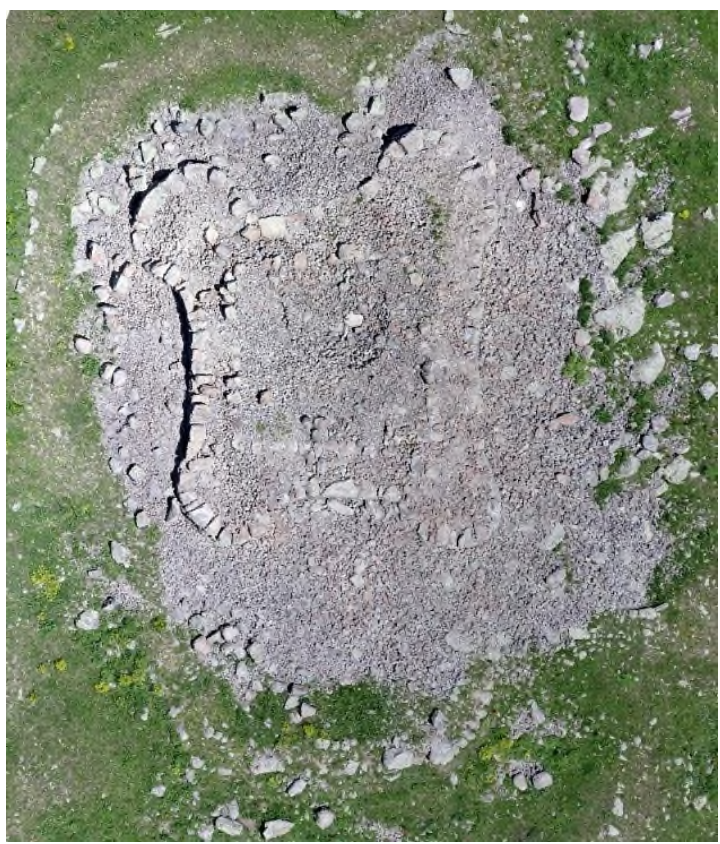

Resim 7. Bellitepe Batı Kulesi'nin havadan görünümü. 


\section{Ardahan İli 2017 Yılı Arkeolojik Yüzey Araştırması}

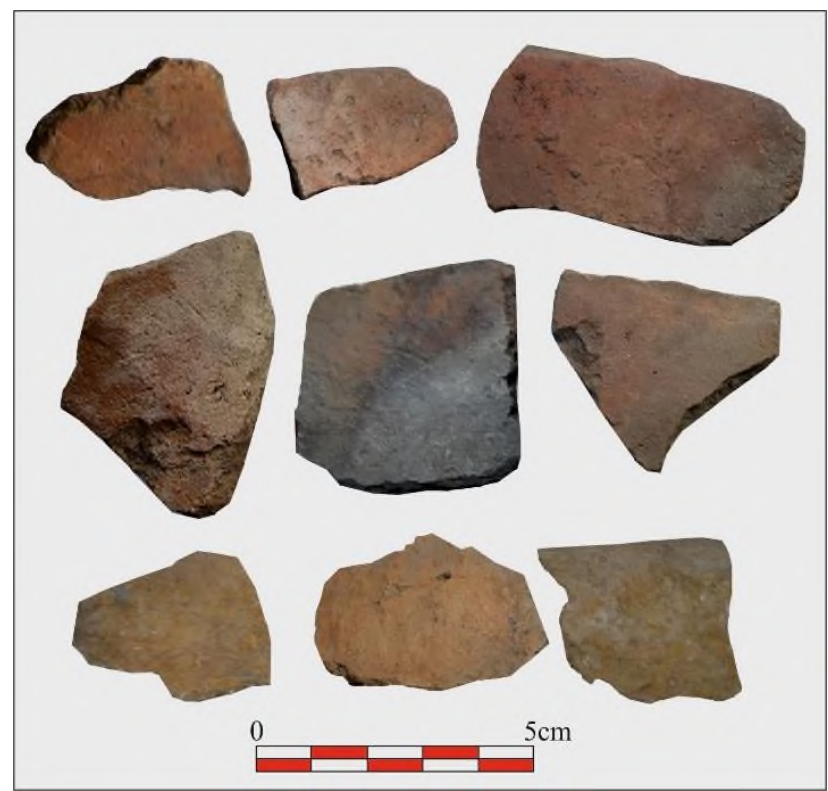

Resim 8. Bellitepe-Batı Kulesi'nden çanak-çömlek örnekleri.

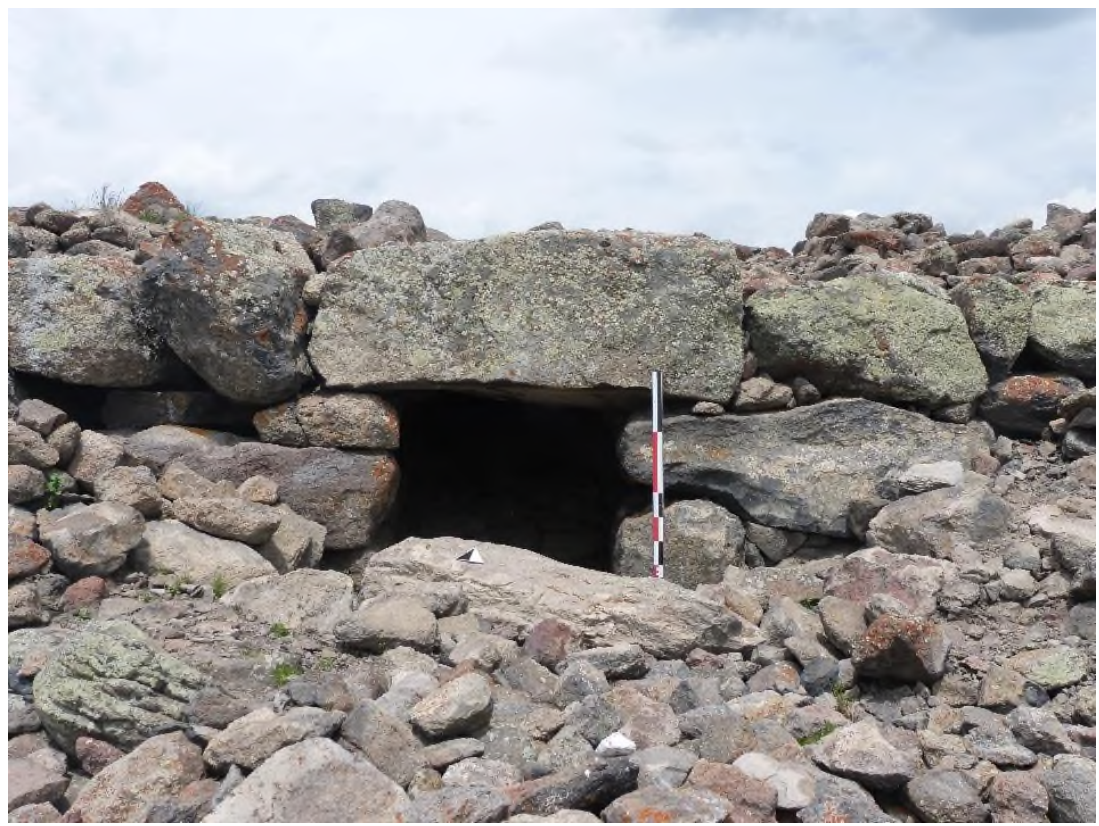

Resim 9. Bellitepe Batı Kulesi'nin girişi. 
Sami PATACI - Özlem ORAL PATACI

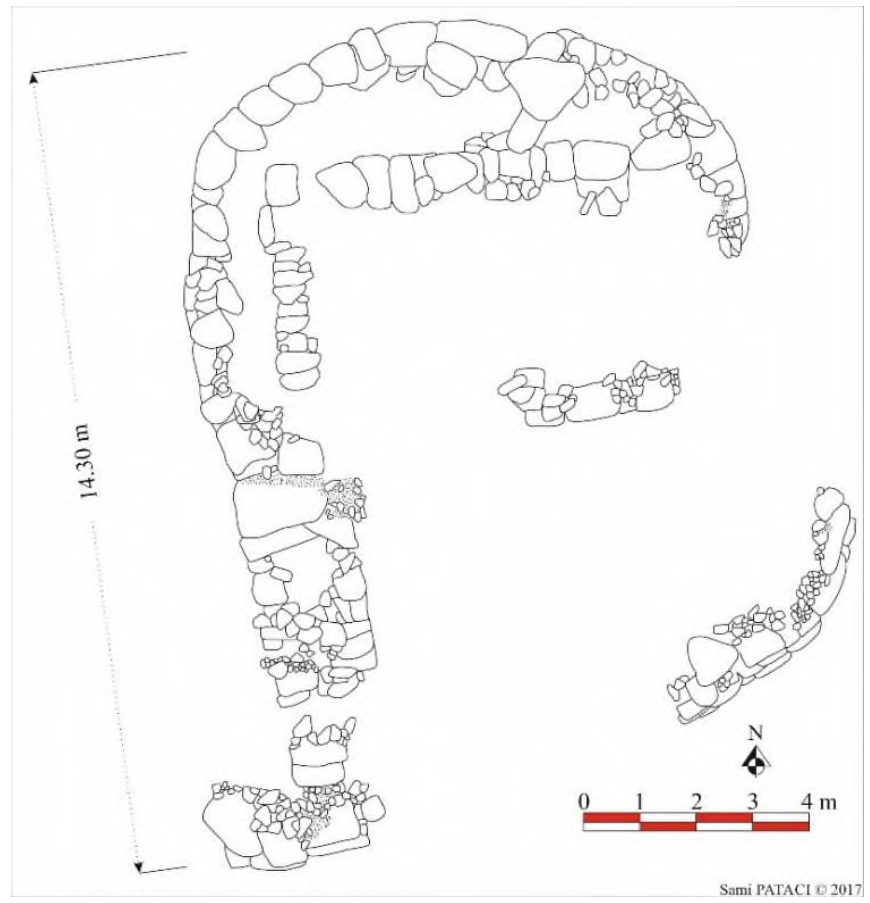

Çizim 5. Bellitepe Doğu Kulesi planı.

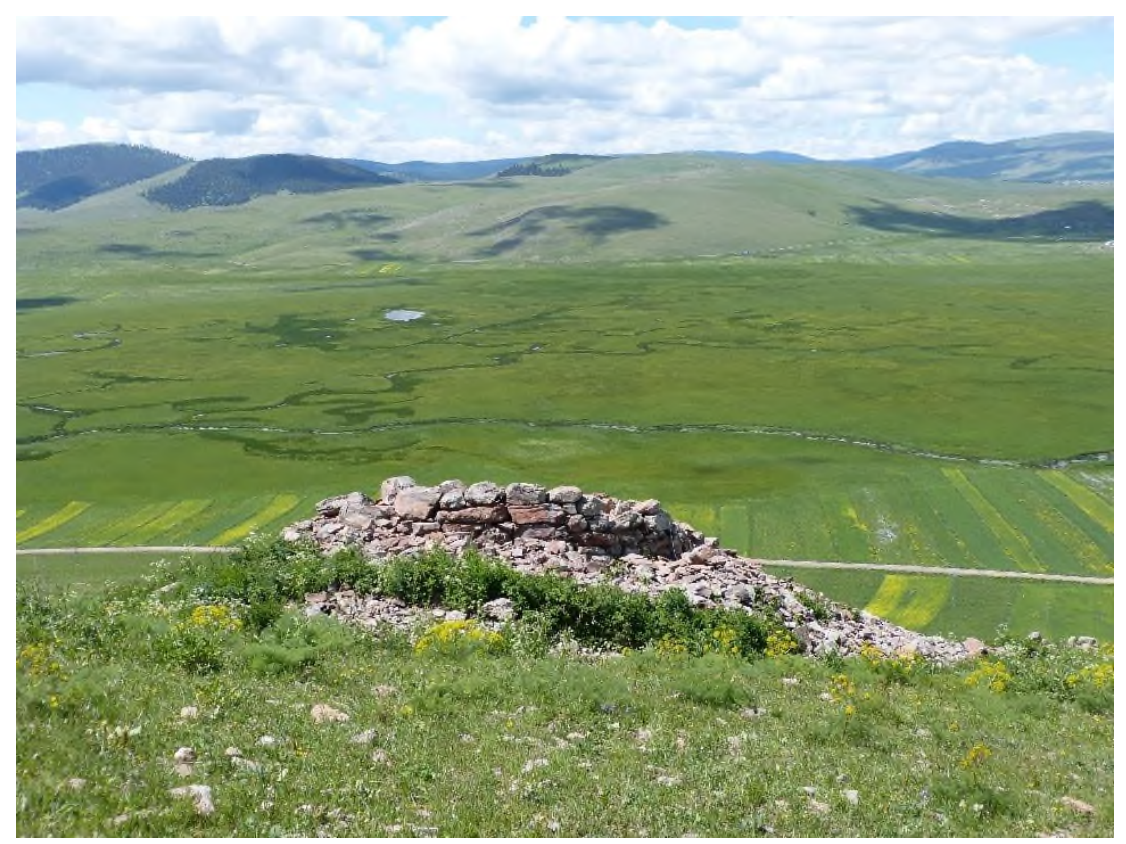

Resim 10. Bellitepe Doğu Kulesi'nin ve hakim olduğu ovanın kuzeyden görünümü. 


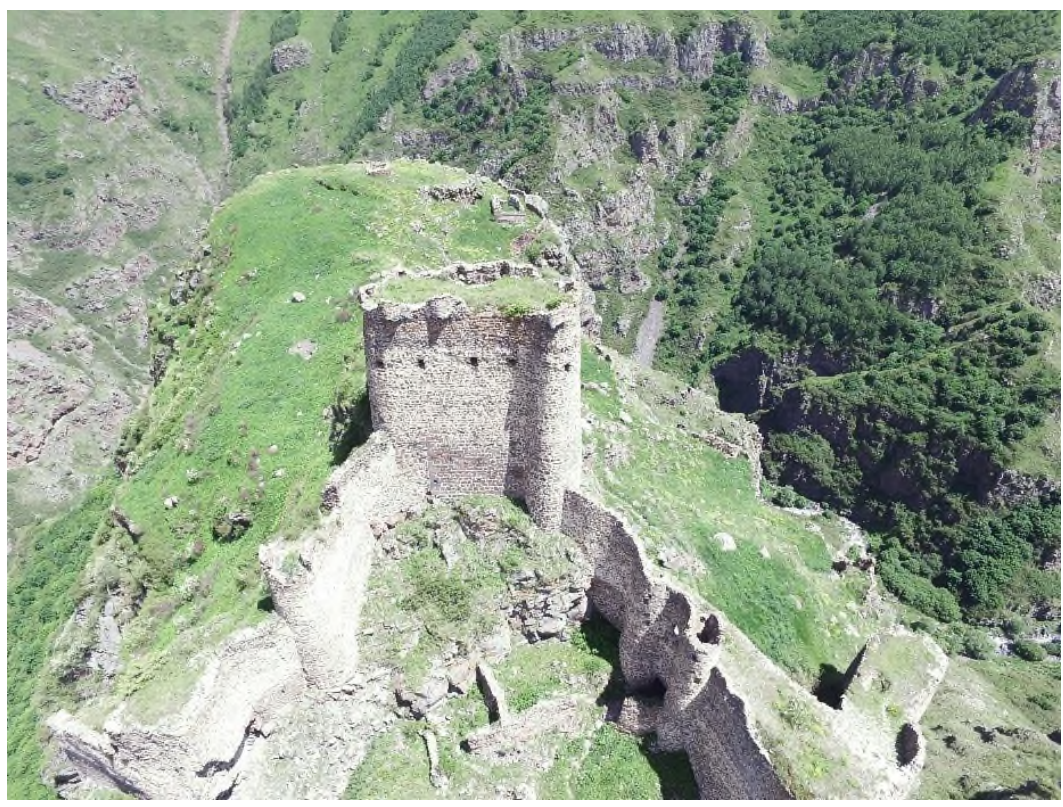

Resim 11. Şeytan Kalesi. Batıdan görünüm.

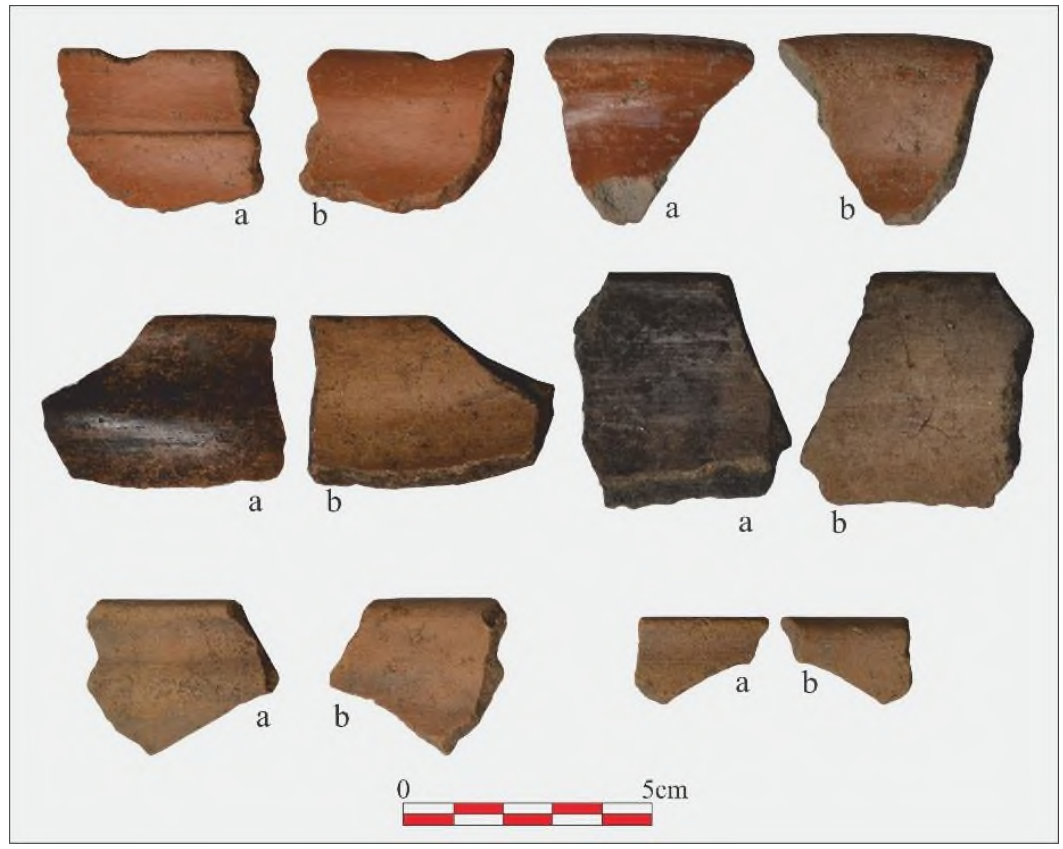


Resim 12. Şeytan Kalesi çanak-çömlek buluntuları.

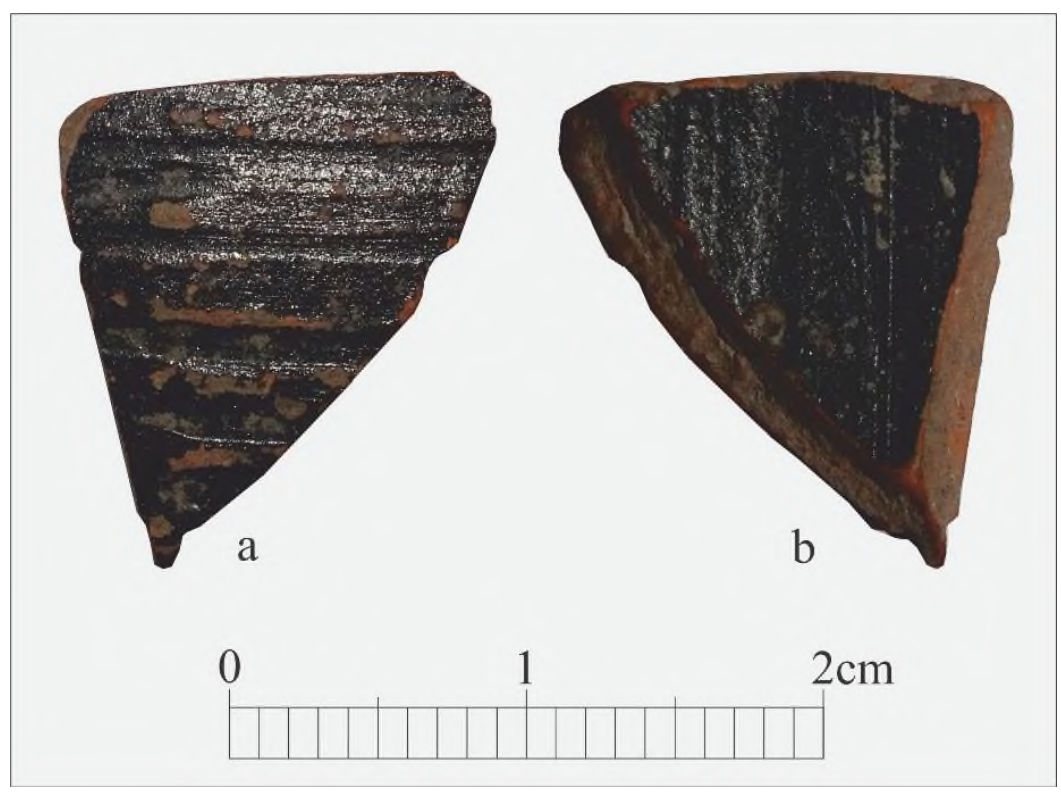

Resim 13. Şeytan Kalesi'nden İ.Ö. 4. yüzylla ait olması gereken bir seramik parçası.

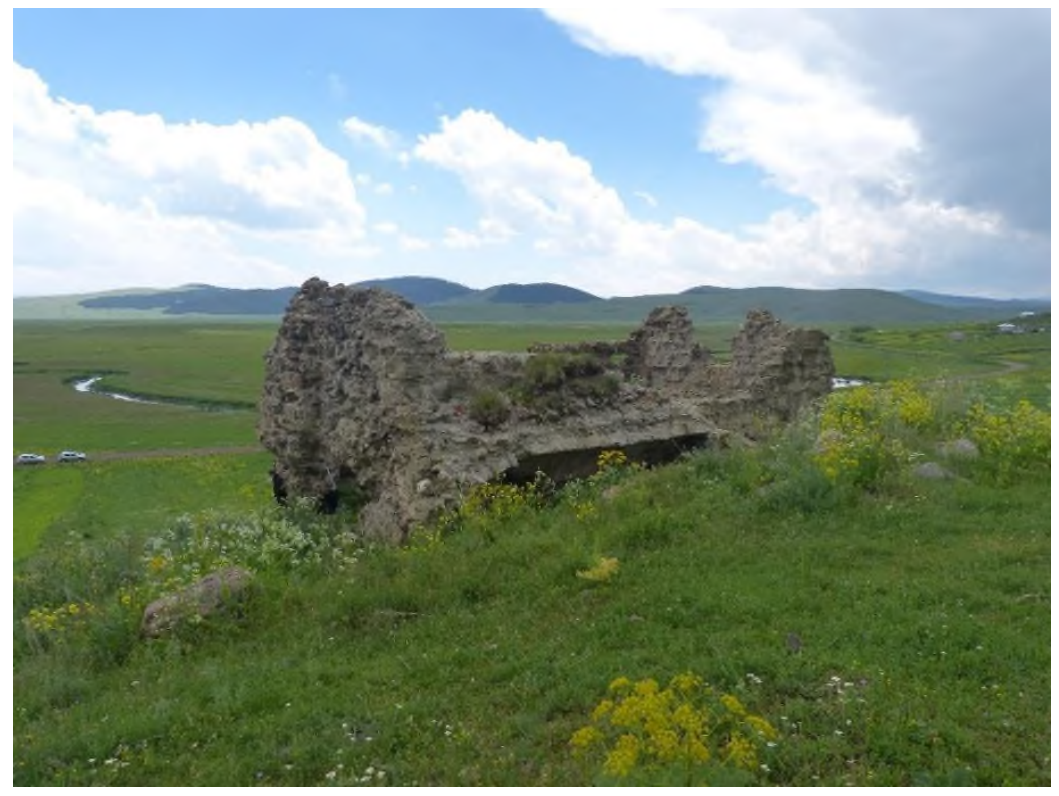

Resim 14. Bellitepe Kilisesi'nin kuzeydoğudan görünümü. 


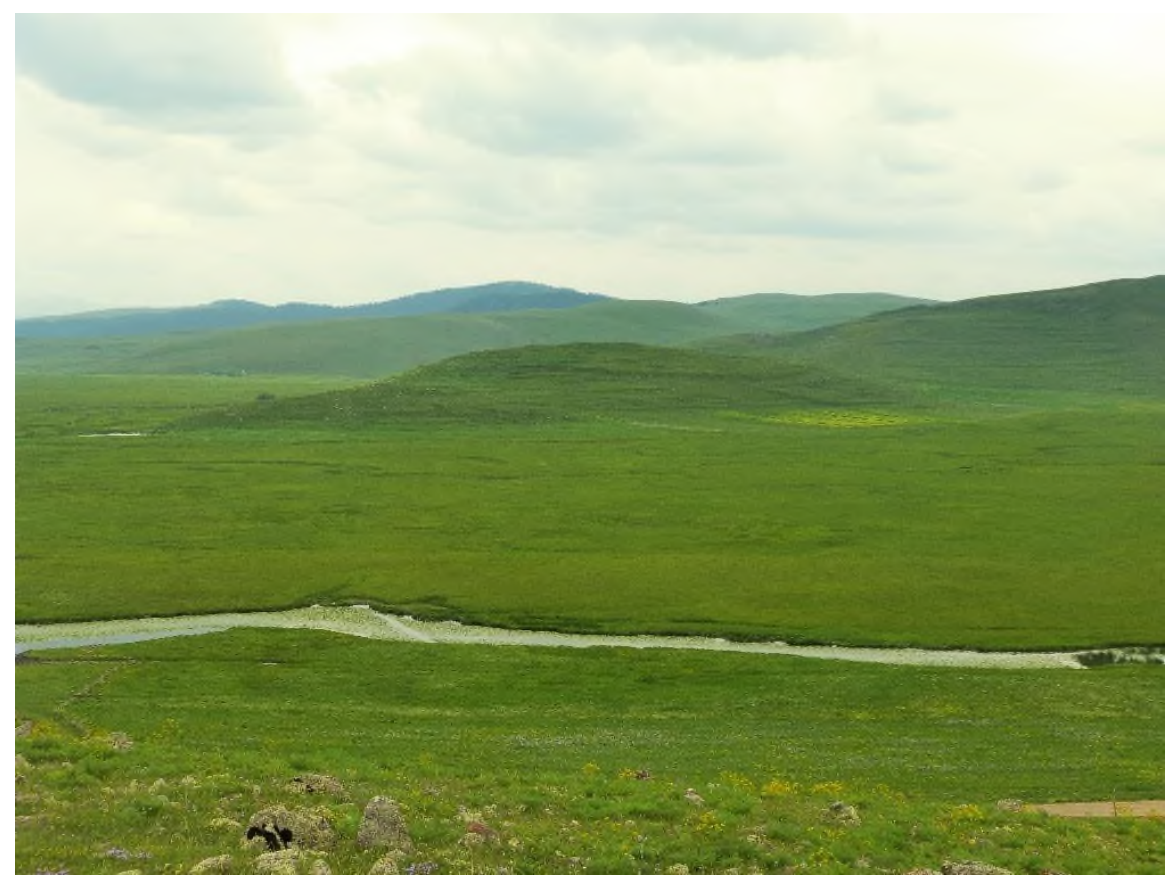

Resim 15. Dedeşen Höyüğü'nün kuzeyden görünümü.

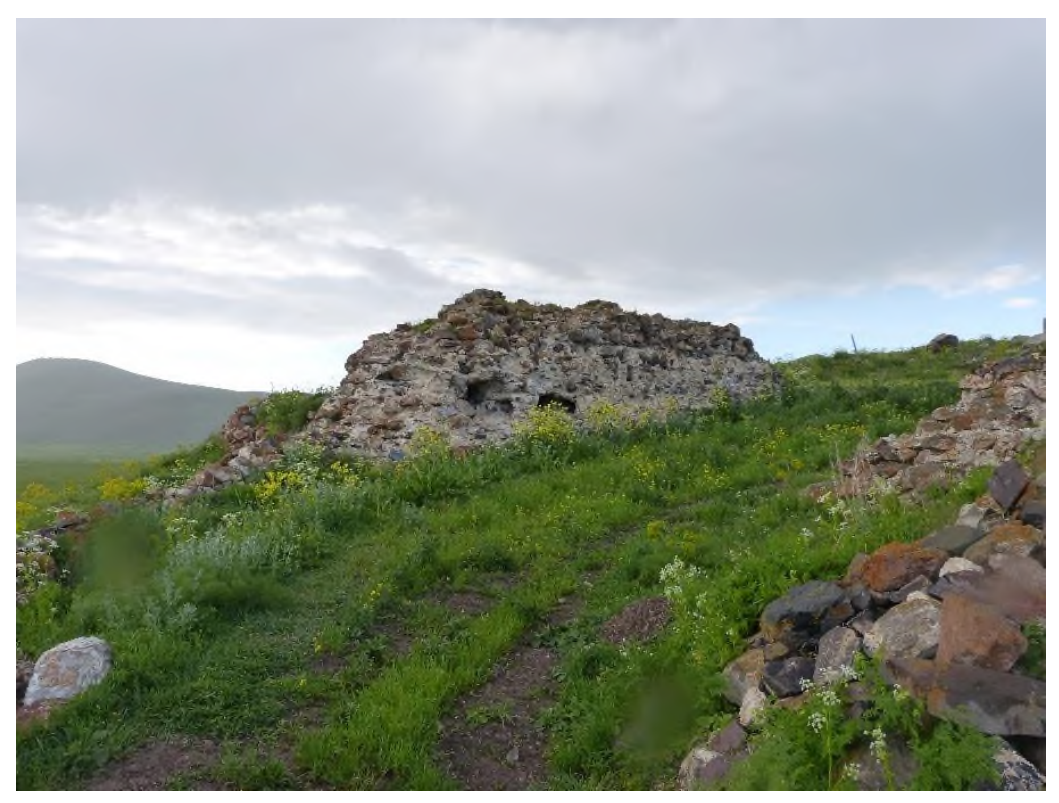

Resim 16. Dedeşen Höyüğü'ndeki sur. 
Sami PATACI - Özlem ORAL PATACI

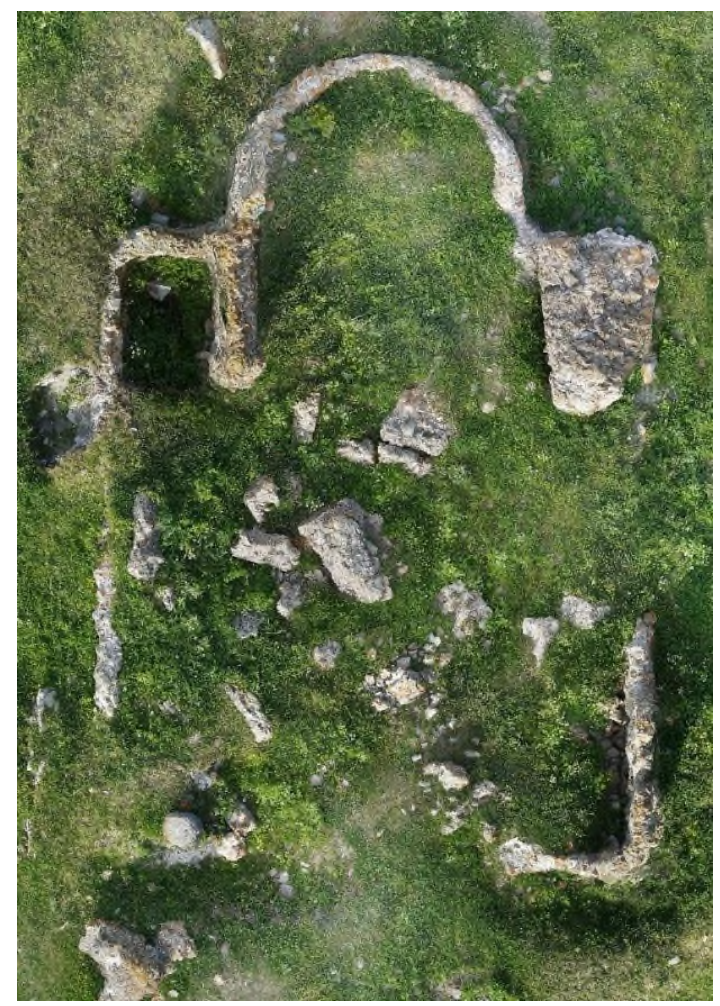

Resim 17. Dedeşen Ortaçağ Kilisesi'nin ortofotosu.

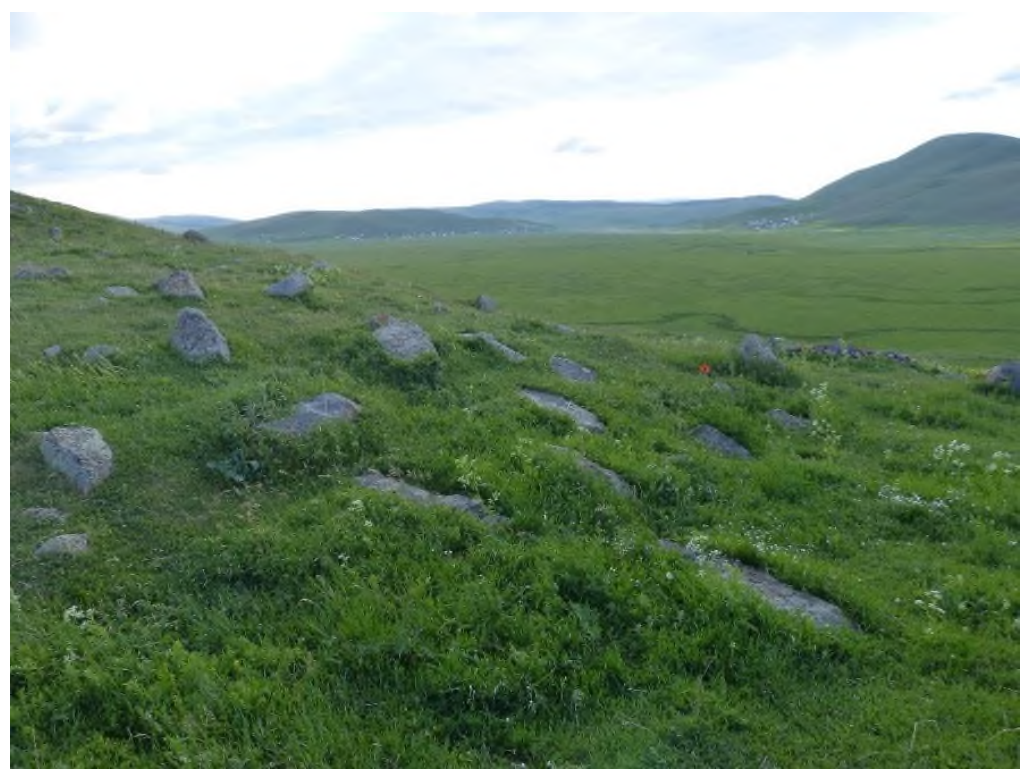

Resim 18. Dedeşen Ortaçağ Mezarlığg 